\title{
3 The V2-Reconstruction Hypothesis
}

In this chapter, I argue that verbs which are attracted by V2-movement have to be reconstructed into their base position for interpretation. Consequently, the lexical meaning of the finite verb is never interpreted in the overt V2-position. I start by motivating and specifying this hypothesis. Thereafter, I present empirical observations in support for the claims that verbs are not interpreted in V2-position (Section 3.2) but that the verb must be interpreted in its base position (Section 3.3). In Section 3.4, I present the results of an acceptability study which investigates claims concerning periphrastic tun, thereby backing up the analysis of Section 3.2. The last section summarizes the results and addresses its consequences.

\subsection{Defining the V2-Reconstruction Hypothesis}

\subsubsection{Introduction}

Based on the well-know and solid generalization that only finite verbs are subject to V2-movement, Bayer \& Freitag (2020) argue that V2-movement is essentially feature movement. The crucial features that are attracted are the finiteness features which are encoded by the inflection at the finite verb. The inflection, however, cannot be separated from the verb for reasons of morphological integrity. Therefore, the verbal stem that carries the inflection has to move as a whole: The verb is piedpiped. Crucially, even though the verb moves to a higher position, it is interpreted in its base position. This V2-Reconstruction Hypothesis ${ }^{1}$ is given in (1).

(1) V2-Reconstruction Hypothesis

The finite verb that appears in 2nd position in a V2-language is in this position only for the reason of generalized pied-piping. Even when it is perceived in V2-position, its lexical part is evaluated in its base position, i. e. in German in clause-final position.

(Bayer \& Freitag 2020: 79)

After a short note that clarifies the necessary concepts in relation to movement, reconstruction, and pied-piping, I will present empirical evidence in support for the V2-Reconstruction Hypothesis in the following two sections. In Part II of this book, I will show that the V2-Reconstruction Hypothesis makes very accurate predictions for the processing of German V2-clauses.

1 Conjecture about V2 in Bayer \& Freitag (2020). This work is licensed 


\subsubsection{Understanding movement, reconstruction, and pied-piping}

Movement can be considered as the establishment of a dependency between two syntactic positions. Such dependencies can be categorized along two parameters: first, movement which is accompanied by an amendment or a change in meaning and second, movement which has no identifiable effect on meaning. In the Minimalist framework (Chomsky 1995), the division between the two interface levels, the Phonetic Form (PF, perceptual-articulatory dimension) and the Logical Form (LF, the conceptual dimension), has been proven to be very useful for the understanding of such dependencies. The types of movement are assumed to exhibit different requirements at the interfaces, such that the meaning-sensitive movement takes place also at LF, whereas the meaning-insensitive movement only takes place at the PF-interface. The four possible combinations of these interface requirements are summarized in Table 3.1.

Table 3.1: Types of movement

\begin{tabular}{|c|c|c|c|}
\hline & & \multicolumn{2}{|l|}{ PF } \\
\hline & & moved & in-situ \\
\hline LF & $\begin{array}{l}\text { moved } \\
\text { in-situ }\end{array}$ & $\begin{array}{l}\text { classical overt movement } \\
\text { PF-movement (pied-piping) }\end{array}$ & $\begin{array}{l}\text { covert movement } \\
\text { in-situ-elements }\end{array}$ \\
\hline
\end{tabular}

Why do elements move? In the minimalist framework, movement (or more appropriately attraction/internal merge) must be triggered by a strong uninterpretable feature. Such an [-interpretable] feature attracts the closest element that bears the appropriate feature to delete the [-interpretable] feature. In this way, an element is moved from its original position to the target position, where it is in some local relation to the attractor. The division of features into movement triggering [-interpretable] and non-triggering features [+interpretable] originates from a conceptual necessity of the derivational model. One should not be confused by the terminology ( \pm interpretable) and assume that movement does not affect interpretation. Right the opposite is the case. Usually, movement is necessary to yield a grammatical/interpretable structure at all.

We can understand movement, or the establishment of a dependency between two syntactic positions, as a way to express two aspects of meaning with one syntactic object. For illustration, take the case of $w h$-fronting in (2). A declarative sentence, such as (2a) can be transformed into a $w h$-question by replacing a syntactic element by a respective $w h$-term, such as the subject in ( $2 \mathrm{~b}$ ) or the object in (2c) (the translations indicate the parallel structures in English). In $w h$-fronting 
languages, such as German and English, the highest wh-term must be placed in clause-initial position.

(2) a. Also hat der Junge diesen Mann gekannt. thus has the boy this man known 'Thus, the boy knew this man.'

b. Wer hat wer diesen Mann gekannt? who.NOM has this man known 'Who knew who knew this man?'2

c. Welchen Mann hat der Junge which man has the boy known 'Which man did the boy know which man?'

Examples (2a) and (2b), however, show that an object can be interpreted in the post-subject position. Therefore, the only properties that need to be interpreted clause-initially in (2c) are the ones that are tied to the interrogative meaning. Following standard assumptions, I assume that quantificational properties are computed at the fronted position, e.g. scope. At the base position, the thematic properties of the object are interpreted, as schematized in (3), see also Sportiche (2006: 40-41).

$$
\begin{aligned}
& \text { (3) }\left[\mathrm{wH}+\mathrm{Object}_{1} \quad \text { Subject Verb } \mathrm{eng}_{1} \text { Object }_{1} \quad \text { Verb }_{\mathrm{deu}}\right. \\
& \text { quantificational properties }
\end{aligned}
$$

Example (4) illustrates the effect of scope marking: In both variants, the wh-term is related to the object of the embedded clause. In (4a), the wh-element only scopes over the embedded clause. Hence, the matrix clause is still declarative. In (4b), on the other hand, the wh-element is moved to the sentence-initial position where it scopes over the matrix and the embedded clause. Hence, the whole sentence is interrogative. Due to the identical base position of the wh-elements in both sentences, the difference in meaning stems from the different target positions of the moved elements.

(4) a. Also hat die Professorin erzählt, welchen Mann der Junge welchen Mann thushastheprofessor told which man theboy gekannt hat. known has 'Thus the professor told which man the boy knew which man.'

2 Clearly, the verb moved at least from V-to-I in English subject-questions. Whether it also moves from I-to-C or not is of no particular interest here. 
b. Welchen Mann hat die Professorin erzählt, dass der Junge henen Mann which man hastheprofessor told that theboy gekannt hat? known has

'Which man did the professor tell that the boy knew which man?'

Overt movement results in a situation in which we have multiple positions for interpretation but only one position in which the respective element is spelled out. This connection has been covered by all theories of movement but is handled most elegantly by the copy theory of movement: Movement creates a copy of the moved material in the target position. Usually, only one of this copies is spelled out at PF - under normal conditions the highest of all copies.

Now, we can evaluate whether there is movement only at PF without a semantic motivation. The answer is yes. It is actually very common that movement affects larger parts than only the element which bears the attracted feature. This phenomenon is known under the term pied-piping (going back to Ross 1967: 196240). As I have shown above, the nominal object [DP Det boy] can be interpreted in-situ, i.e. in its post-subject base position. The reason why wh-terms such as which boy move is that which has to move and which and boy have to be connected by some mechanism. What would be minimally needed for a structure as (5a) is something like the structure in (5b), where the indices indicate the association of the two elements.

(5) a. Welchen Mann hat der Junge

which man has the boy known

'Which man did the boy know which man?'

b. * Welchen $_{\mathrm{i}}$ hat der Junge welchen Mann $_{\mathrm{i}}$ gekannt? which has the boy known

‘`Which did the boy know which man?’

However, frequently, we observe that movement affects larger parts than actually expected, such as in (5a). In such cases, we say that boy is pied-piped by the element which. The element boy does not move because it bears the attracted feature but because it stands in a relation with an element that bears such a feature. The reason why boy moves together with which is that the relation between these two elements must not be broken by destroying their local configuration. In (5a) the pied-piping element is the phrase structural head that takes its complement along. The same element may also pied-pipe an exponent of a higher structure, such as in (6). The determiner which is a complement to the head mit 'with'. Nevertheless, in German, such a preposition cannot be left behind as in (6b) but must be fronted 
along with the DP, as in (6c). The rationale is the same here: The local relation between the preposition and its complement DP must not be destroyed (see Bayer \& Bader 2007). Under certain conditions, however, we observe split phenomena, for example preposition stranding in English (Hornstein \& Weinberg 1981), indicated by the grammatical translation in (6b), or was-für-splits in German (den Besten 1985).

(6) a. Dann hat der Junge mit diesem Mann telefoniert. Then has the boy with this man called 'Then the boy talked to this man over the phone.'

b. * Welchem Mann hat der Junge [mit welchem Mann] telefoniert? which man has the boy with called 'Which man did the boy talked to which man over the phone?'

c. Mit welchem Mann hat der Junge [mit welchem Mann] telefoniert? with which man has the boy called 'To which man did the boy talked to which man over the phone?'

If an element has moved but is interpreted in a position in which it has been "before", we say it has been reconstructed. Reconstruction has been discussed almost exclusively for phenomena including binding and scope relations (i.e. quantificational operators), and this for a good reason: binding and scope require a ccommand relation between two elements, i. e. a specific hierarchical configuration. This requirement for c-command acts as a robust diagnostic for the actual position of interpretation. Therefore, reconstruction might apply in many more cases for which we just lack a diagnostic to properly identify it (see Chomsky 1976: 332-336, Huang 1993, Bayer 1993: 23-27, and Sportiche 2006 for a comprehensive overview of reconstruction).

Classic examples to illustrate reconstruction effects are condition $\mathrm{C}$ violations. ${ }^{3}$ Consider example (7). In (7a) the pronoun ihn 'him' can be coreferent with Uwe because only the phrase containing the R-expression Uwe c-commands the pronoun. In (7b), on the other hand, the subject pronoun er 'he' cannot be coreferent with Uwe because the pronoun now asymmetrically c-commands the R-expression, which violates principle $\mathrm{C}$.

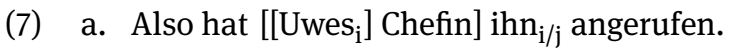

thus has Uwe's boss him called

'Thus Uwe's $\mathrm{i}_{\mathrm{i}}$ boss called $\operatorname{him}_{\mathrm{i} / \mathrm{j}}$ '

3 This refers to Principle $\mathrm{C}$ of the Binding Theory: $\mathrm{R}$ (eferential)-expressions, such as the proper name Uwe, must be free, i. e. must not be c-commanded by a coreferential element (Chomsky 1981: 101-103, 188). 
b. Also hat er ${ }_{*_{\mathrm{i} / \mathrm{j}}}\left[\left[\right.\right.$ Uwes $\left._{\mathrm{i}}\right]$ Chefin] angerufen. thus has he Uwe's boss called 'Thus, he $\star_{\star_{i} / \mathrm{j}}$ called Uwe's $s_{\mathrm{i}}$ boss.'

Now, consider example (8), in which the complex DP Uwes Chefin 'Uwe's boss' is fronted into Spec-CP (topcalized). In (8a), the fronting does not alter the ccommand relation between the R-expression and the object pronoun: Spec-CP as well as the subject position c-command the object position. In (8b), on the other hand, the overt position of the R-expression, Spec-CP, is not in the c-command domain of the subject pronoun er 'he' but only the base position of the object. Nevertheless, we observe the same coreference options as in (7b), which indicates that binding is evaluated with respect to the base position of moved constituents.

a. [Uwes ${ }_{i}$ Chefin] hat $\left[\right.$ Uwes $_{i}$ Chefin] ihn $_{i / j}$ angerufen. Uwe's boss has him called

'Uwe's $\mathrm{s}_{\mathrm{i}}$ boss called him $\mathrm{i}_{\mathrm{i} / \mathrm{j}}$ '

b. [Uwes $s_{i}$ Chefin] hat $\mathrm{er}_{\mathrm{*}_{\mathrm{i} / \mathrm{j}}}$ [Uwes ${ }_{\mathrm{i}}$ Chefin] angerufen. Uwe's boss has he called

'It was Uwe's ${ }_{i}$ boss he ${ }_{*_{i} / \mathrm{j}}$ called Uwe's boss.'

Also relevant in the context of the V2-Reconstruction Hypothesis is the observation that movement which involves (parts of) predicates must obligatorily reconstruct, also in cases of phrasal A-bar movement such as VP-topicalization or topicalization of a predicative adjective (Heycock 1995, Sportiche 2006: 61-62). Hence, V2-moved finite verbs are in good company. Furthermore, Sauerland \& Elbourne (2002) argue that (total) reconstruction applies only to cases of PF movement, such as pied-piping. Therefore, two aspects of the V2-Reconstruction Hypothesis receive independent support: Verbs as well as pied-piped elements reconstruct, therefore it is very likely that pied-piped verbs will do so too.

Movement which takes place at both levels, on the surface (PF) and accompanied by a change in meaning (LF), triggers two interpretation processes in language comprehension. In the literature on sentence processing this has been extensively studied under the term filler-gap dependency (see Section 4.2.2). Oversimplified, the processor computes one set of properties in the target position and another set of properties in the base position, as illustrated for quantificational properties and thematic properties in (3) and (4). 


\subsubsection{Outlook}

The V2-Reconstruction Hypothesis actually consists of two interrelated claims: First, the lexical content of the finite verb is only pied-piped to the C-position. Second, the finite verb undergoes obligatory reconstruction, i. e. it is interpreted in its base position. In the following, I will list several empirical phenomena in support of the V2-Reconstruction Hypothesis by providing independent evidence for the validity of both claims. ${ }^{4}$ The arguments of the first class support the claim that only the finiteness features are attracted by V2-movement and not (the lexical content of) the verb (Section 3.2). I discuss particle verbs, periphrastic-tun constructions, verb doubling constructions, Frisian wer-insertion, and complementizer agreement. They all have in common that finiteness features are expressed in the C-domain although the lexical verb (or parts of it) is present in the clause-final base position or in Spec-CP. The second class of observations, Section 3.3, contains association with focus, verbal negative polarity items, and sentential negation. These have in common that they require configurations in which the finite verb must be c-commanded by a certain operator. Crucially, only the clause-final base position but not the $\mathrm{C}$-position lies within the c-command domain of the respective operators. This indicates that the meaning of the verb is interpreted in the clause-final position. Thus, these two complementary classes of arguments provide support for the two basic assumptions of the V2-Reconstruction Hypothesis: Movement only targets the finiteness features and the verb has to be reconstructed for semantic interpretation.

\subsection{The C-position: Challenging a lexical contribution at the surface position}

\subsubsection{Particle verbs: V-to-C as movement of phonological words}

German exhibits a class of complex verbs, so called particle verbs, which consist of a verbal base and a prefixed particle, usually of prepositional origin. If V2movement applies to a finite particle verb, only the inflected verbal base moves to the V2-position. The particle remains stranded in the base position, as illustrated in (9a) and (9b). The combination of particle and verb can be transparent,

\footnotetext{
4 The arguments in Section 3.2 and Section 3.3 have already be published in Bayer \& Freitag (2020). Some of those observation were adapted from an earlier manuscript (Bayer 2008), namely periphrastic tun (Section 3.2.2), verb doubling (Section 3.2.3), association with focus (Section 3.3.1), and negative polarity items (Section 3.3.2).
} 
as in (9), and related lexemes, such as abkaufen (of+buy 'buy from so.'), ankaufen (on+buy 'purchase'), or zukaufen (to+buy 'buy in addition'), which are all flavors of buying. The particle verb in (10) is an example of a non-compositional meaning, auf-führen (on-lead) 'perform'.

(9) a. Uwe kauft einen Apfel ein.

Uwe buys an apple in

'Uwe buys an apple.'

b. ... dass Uwe einen Apfel einkauft. that Uwe an apple in.buys

'... that Uwe buys an apple.'

(10) Nicole führt eine Oper auf.

Nicole leads an opera on

'Nicole performs an opera.'

The contrast pair in (11) shows that one and the same combination of particle and verb abhauen (off+chop) can have a compositional meaning 'chop off' as in (11a) or it can have an idiosyncratic meaning 'leave quickly' as in (11b).

(11) a. Sie haut den Ast mit einer Axt ab. she chops the branch with an axe off 'She chops off the branch with an axe.'

b. Sie haut vor der Polizei ab. she chops from the police off 'She leaves quickly from the police.'

All the examples above illustrate that V2-movement does not target the semantic word but a smaller unit. This implies that the verb cannot be interpreted in $\mathrm{C}$ because it is incomplete. Kremers (2009) proposes to capture the regularities of particle verb movement by mapping rules between the syntactic and the phonological structure. ${ }^{5}$ The relevant units for the mapping in the present discussion are phonological phrases $(\varphi)$, which typically correspond to syntactic phrases, and prosodic words $(\omega)$, which typically correspond to syntactic heads. Kremers (2009) assumes that particle verbs consist of two separate prosodic words, one for the verb and one for the particle, as illustrated in (12) as an analysis of (9b). The particle verb as a whole is a phonological phrase. ${ }^{6}$

5 In Chapter 4, I will introduce a similar mapping for language processing (comprehension).

6 Kremers (2009) formulates conditions and mapping restrictions to cover the observation that particles of particle verbs behave like phrases if they are separated from the verbal base, as indi- 
(12)

Uwe einen Apfel ein kauft
$\{\omega\}_{\varphi}\left\{\begin{array}{lll}\omega & \omega\end{array}\right\}_{\varphi}\left\{\begin{array}{ll}\omega & \omega\end{array}\right\}_{\varphi}$

The analysis of particle verbs as two separate prosodic words also offers an explanation for the observation that inflectional morphemes, such as the infinitive marker $z u$ 'to', may attach directly to the verb, thereby intervening between particle and verb, as shown in (13).

(13) ohne einen Apfel ein-zu-kaufen

without an apple in-to-buy

'without buying an apple'

cated by adverbial modification, whereas they behave like heads if they appear adjacent to the verbal base, where they cannot be modified, as shown in (i.b) and (ii.b). Note, however, that additional movement of the particle (verb raising) is necessary to yield this contrast in (ii.b), i.e. modification of the particle is fine in the non-derived base position, as in (ii.a) and (iii.a). The respective contrasts in German, however, seem to be very subtle if at all present, as indicated in (iii).

(i) a. John threw the ball (right) in.

b. John threw ( ${ }^{*}$ right) in the ball.

(see Kremers 2009: 86)

(ii) DUTCH

a. ... dat Jan de bal (vlak) over geschoten heeft that Jan the ball right over shot has '... that John kicked the ball just over the goal'

b. ... dat Jan de bal $\mathrm{t}_{1}$ heeft [( ${ }^{*}$ vlak) over geschoten $]_{1}$ that Jan the ball has right over shot

c. ... dat Jan de bal (vlak) over $\mathrm{t}_{1}$ heeft [geschoten] $]_{1}$ that Jan the ball right over has shot

(see Kremers 2009: 86)

(iii) GERMAN

a. ... dass Jan den Ball (richtig) drübergeschossen hat. that Jan the ball right over shot has '... that Jan shot the ball right over (the goal)'

b. [(Richtig) drüber $]_{1}$ hat Jan den Ball $\mathrm{t}_{1}$ geschossen. right over has Jan the ball shot. 'Jan shoots the ball right over (the goal).'

c. [(?Richtig) drübergeschossen $]_{1}$ hat Jan den Ball $\mathrm{t}_{1}$. right over shot has Jan the ball 
The observation that V2-movement only targets the verbal base of particle verbs can now be expressed by a mapping rule, as in (14). This rule states that the Cposition is a head position that may only be filled by a single head that maps onto a single prosodic word $(\omega)$. There is no room for two prosodic words or a phonological phrase. Hence the particle must remain in its underlying position.

(14) $\quad \mathrm{C} \leftrightarrow \omega$

(Kremers 2009: 92)

In this section, I have pointed out two generalizations concerning particle verbs: First, the separability of particle verbs by V2-movement is independent of semantic compositionality. Second, V2-movement targets only the smallest possible unit, i. e. a prosodic word. These two generalizations indicate that V2-movement is a semantics-free operation based on morphophonological properties (more on the perspective of interpreting particle verbs is discussed in Section 4.3.4). The conclusion about particle verbs is in line with the V2-Reconstruction Hypothesis in (1): V2-movement is a mechanism to bring finiteness features into the C-position. Aspects of the lexical verb are of no importance. Consequently, the meaning of particle verbs, compositional or idiomatic, is interpreted in the clause-final base position.

\subsubsection{Semantically empty host I: Periphrastic tun}

German exhibits several constructions with the verb tun 'do'. Very common are light verb constructions as in (15).

a. einen Gefallen tun

a favor do

'do a favor'

b. Leid tun

sorrow do

'be/feel sorry'

Despite these expressions, certain registers and dialectal variants also allow the tun-periphrasis. In such constructions, tun cooccurs with another verbal element and functions as a finite auxiliary (Fischer 2001). It has been noted that, in some dialectal variants, the tun-periphrasis may be used to express conjunctive and to mark aspect (Abraham \& Fischer 1998, Kölligan 2004, Schwarz 2004). I will exclude those cases from the discussion and focus solely on the indicative use. 
The tun-periphrasis is more frequent with tun in V2-position ${ }^{7}$, as in (16a), but is also acceptable in V-final position, as in (16b).

a. Der Junge tut gerade die Wand streichen.

the boy does currently the wall paint

'Currently the boy is painting the wall.'

b. Ich glaube, dass der Junge gerade die Wand streichen tut.

I believe that the boy currently the wall paint does

'I believe that boy is currently painting the wall.'

It must be noted that the periphrastic construction is a fully optional variant ${ }^{8}$ to an inflected lexical verb. Abraham \& Fischer (1998) assume that the tun-insertion is primarily a means of receiving neutral accent on the clause-final verb. This explains why tun appears more frequently in V2-position than in V-final position. Accordingly the tun-periphrasis is quite unacceptable in combination with periphrastic tense forms that already involve an auxiliary (Abraham \& Fischer 1998: 37).

Crucially, the use of periphrastic tun is semantically/pragmatically restricted. The exact classification in the literature differs slightly: agentive vs. non-agentive verbs (Fischer 2001: 40), eventive vs. stative verbs (Maienborn 2003: 54-63, Rothmayr 2009: 28-31, Hoekstra 2016: 342), telic vs. atelic verbs (Schönenberger \& Penner 1995: 318-319), and individual-level vs. stage-level predicates (Bayer \& Freitag

7 The tun-periphrasis also occurs in the C position in V1-clauses, such as in the imperative and interrogative clauses in (i), see also Erb (2001: 183-191) for the compatibility with any sentence type.

(i) a. Imperative

Tut euch nich bekleckern

do you not blot

'Don't blot yourselves!'

b. Interrogative

Tust du pflügen?

do you plow

'Do you plow?'

(Abraham \& Fischer 1998: 38, 40)

8 Despite its superficial similarity, the tun-periphrasis is not comparable to the English dosupport. They have in common that they are elements for the realization of finiteness features and can be replaced by modal verbs or other auxiliaries, thereby receiving a different interpretation. They differ in their distribution: English do-support (in absence of another non-thematic verb) is obligatory in wh-questions and with sentential negation. In German there is no need for an expletive auxiliary in those environments. German requires an expletive auxiliary in case of a topicalized verb to satisfy the V2-requirement, which lacks an equivalent in English. 
2020). The discussion and the results of Experiment 1 (Section 3.4) will reveal that the situation is more complex than a 2-way distinction. It will turn out that only a subgroup of stative verbs do contrast significantly with agentive verbs, as predicted by Maienborn (2003) and Rothmayr (2009). The validity of the present argument, however, does not hinge on the exact characterization of the predicate classes. For simplicity, here, I will follow the characterization of Bayer \& Freitag (2020) that periphrastic tun is compatible with stage-level predicates but incompatible with individual-level predicates. ${ }^{9}$ The incompatibility of individual-level predicates own, resemble and lie on a lake is illustrated in (17) in contrast to the non-periphrastic equivalents in (18).

(17) a. * Der Junge tut einen guten Charakter besitzen. the boy does a good character own 'The boy has a good character.'

b. * Der Junge tut seinem Vater ziemlich ähneln the boy does his fathermuch resemble 'The boy resembles his father quite a lot.'

c. * Konstanz tut am Bodensee liegen Constance does at the Lake Constance lie 'Constance lies on Lake Constance.'

(18) a. Der Junge besitzt einen guten Charakter. the boy owns a good character 'The boy has a good character.'

b. Der Junge ähnelt seinem Vater ziemlich. the boy resembles his father much 'The boy resembles his father quite a lot.'

c. Konstanz liegt am Bodensee. Constance lies at the Lake Constance 'Constance lies on Lake Constance.'

The same effect can be observed for VP-pronominalization (Hoekstra 2016: 342). In coordinations, the VP of the second conjunct can, under identity, be expressed by a weak pronoun es or a d-pronoun das. The position of the finite verb in the second conjunct is filled with a periphrastic tun, as shown in (19) with the stagelevel predicate paint.

9 In a nutshell, stage-level predicates describe temporary or transitory properties, such as jump or being hungry, whereas individual-level predicates denote rather permanent properties, such as being smart (see Kratzer 1995). 
(19) Der Junge streicht lvp $_{\text {gerade }}$ die Wand streicht $]_{i}$ und seine Nachbarin the boy paints currently the wall and his neighbor tut $\mathrm{es}_{\mathrm{i}} / \mathrm{das}_{\mathrm{i}}$ auch.

does it/that too

'The boy paint the wall and his neighbor does so/it too.'

The examples in (20) show that this very construction is impossible with individuallevel predicates. Furthermore, the contrast in (21) shows that individual-level predicates are not incompatible with VP-pronominalization as such. If periphrastic tun is replaced by an auxiliary or modal verb, VP-pronominalization is acceptable.

(20) a. Der Junge besitzt [einen guten Charakter besitzt $]_{\mathrm{i}}$ ( ${ }^{\star}$ und seine Freundin the boy owns a good charackter and his girlfriend tut $\mathrm{es}_{\mathrm{i}} / \mathrm{das}_{\mathrm{i}}$ auch).

does it/that too

'The boy has a good character and his girlfriend ( ${ }^{\star}$ does so) too.'

b. Der Jungeähnelt [seinem Vater ziemlichähnelt $]_{i}\left({ }^{\star}\right.$ und sein Bruder the boy resembleshis fathermuch and his brother tut $\mathrm{es}_{\mathrm{i}} / \mathrm{das}_{\mathrm{i}}$ auch).

does it/that too

'The boy resembles his father quite a lot and his brother ( ${ }^{\star}$ does so) too.'

c. Konstanz liegt [am Bodensee liegt $]_{\mathrm{i}}$ ( ${ }^{\star}$ und Friedrichshafen

Constance lies at the Lake Constance and Friedrichshafen

tut $\mathrm{es}_{\mathrm{i}} / \mathrm{das}_{\mathrm{i}}$ auch).

does it/that too

'Konstanz lies on Lake Constance and Friedrichshafen ( ${ }^{\star}$ does so) too.'

(21) a. Der Junge könnte [einen guten Charakter besitzten] $]_{i}$ (und seine the boy could a good charackter own and his

Freundin müsste $\mathrm{es}_{\mathrm{i}} / \mathrm{das}_{\mathrm{i}}$ auch).

girlfriend must it/that too

'The boy could have a good character and his girlfriend should have one too.'

b. Der Junge hat [seinem Vater ziemlich geähnelt $]_{i}$ (und sein Bruder hat the boy has his father much resembled and his brother has $\mathrm{es}_{\mathrm{i}} /$ das $_{\mathrm{i}}$ auch).

it/that too

'The boy resembled his father quite a lot and his brother did too.' 
c. [In a guessing game or riddle] Konstanz muss [am Bodensee liegen] $]_{\mathrm{i}}$ (und Friedrichshafen Constance must at the Lake Constance lie and Friedrichshafen muss $\mathrm{es}_{\mathrm{i}} /$ das $_{\mathrm{i}}$ auch). must it/that too 'Constance have to lie on Lake Constance and Friedrichshafen have to too.'

A similar contrast arises in pseudoclefts. ${ }^{10}$ Again, stage-level predicates, as in (22), are fine, whereas individual-level-predicates in (23) are out.

(22) Was der Junge tat, war die Wand streichen. what the boy did was the wall paint 'What the boy did was paint the wall.'

(23) a. * Was der Junge tat, war einen guten Charakter besitzen. what the boy did was a good character own 'What the boy did was have a good character.'

b. * Was der Junge tut, ist seinem Vater ziemlich ähneln. what the boy does is his fathermuch resemble 'What the boy does is resemble his father quite a lot.'

c. * Was Konstanz tut, ist am Bodensee liegen. what Constance does is at the Lake Constance lie 'What Constance does is lie on Lake Constance.'

The data indicates that periphrastic tun is not completely semantically empty but retains some meaning that renders it incompatible with individual-level predicates. This is the result of an automatic reconstruction into its clause-final position where the semantic restriction is evaluated in the verbal complex.

Crucially, however, the semantics of tun can be suspended. This is the case in VP-topicalization, as shown in (24) with individual-level predicates.

(24) a. [vP Einen guten Charakter besitzen] tut der Junge auf alle Fälle.

a good character own does the boy in any cases 'The boy has a good character in any case.'

b. [vP Seinem Vater ähneln] tut nur der Junge.

his father resemble does only the boy

'Only the boy resembles his father.'

10 See Iatridou \& Varlokosta (1998) for an overview of this construction. 
c. [vp Am Bodensee liegen] tut Stuttgart zum Gück nicht. at the Lake Constance lie does Stuttgart luckily not 'Luckily, Stuttgart does not lie on Lake Constance.'

What is the difference between these constructions and the other uses of periphrastic tun? In VP-topicalization, the thematic verb and, optionally, also other elements within the VP move to Spec-CP. This is unproblematic with analytic verb forms, as in (25). Here, the auxiliary carries the finiteness features and moves to C. Things are different with synthetic verb forms. When the predicate has been moved to Spec-CP, no finite verb is left to satisfy the V2-requirement, as illustrated in (26b). The finiteness features also cannot occupy the C-position alone, as indicated in (26c), because of morphological integrity. In this case, tun is inserted as a host for the finiteness features as a last resort operation, yielding (26d). In contrast to the optional cases of periphrastic tun above, tun-insertion to satisfy the V2-requirement in VP-topicalization is obligatory.

(25) $[\text { Gestrichen }]_{1}$ hat $_{2}$ der Junge die Wand gestrichen ${ }_{1}$ hat $_{2}$.

painted has the boy the wall

'The boy painted the wall.'

(26) a. (dass) der Junge die Wand streich-t

that the boy the wall paint-3sG

b. ${ }^{\star}\left[\right.$ Spec-CP streich- $\left.t_{1}\right][C, \varnothing]$ der Junge die Wand streich- $t_{1}$.

paint-3sG the boy the wall

c. ${ }^{*}\left[\right.$ Spec-CP streich $\left._{1}\right]\left[\mathrm{C} \varnothing-\mathrm{t}_{2}\right]$ der Junge die Wand streich ${ }_{1} \mathrm{t}_{2}$.

paint 3sG the boy the wall

d. $\quad\left[\right.$ Spec-CP $s$ treich ${ }_{1}$-en] $\left[\mathrm{C}\right.$ tu- $\left.\mathrm{t}_{2}\right]$ der Junge die Wand streich $\mathrm{h}_{1}-\mathrm{t}_{2}$. paint-INF do-3sg the boy the wall

'The boy paints the wall.'

The VP is fronted for information structural reasons, such as emphasizing a contrast, as illustrated in (27). ${ }^{11}$ Tun must be inserted into C in order to satisfy the

11 Parts of the verb can also receive information structural marking in canonical word order, such as contrastive focus on the thematic verbs in clause-final position in (i.a). Even tun can receive the main accent to mark verum focus, as shown in (i.b). The semantics of tun, however, is still active, as illustrated in (ii).

(i) a. Contrastive focus

Wirtun heut noch SÄEN, PFLÜGEN Und FÜTTERN.

We do.1PL today still sow.INF plow.inf and feed.inf

'Today we still do sow, plow, and feed.' 
V2-requirement. It does not originate from a lower projection and cannot be reconstructed into the clause-final position. Therefore, no semantic incongruity with individual-level predicates arises. VP-topicalization thus further supports the hypothesis that V2 is actually Features2. No lexical verb has to take part in V2-movement.

(27) Ich liebe dich noch immer, aber [mögen $]_{1}$ tu ich dich schon lang I love you still but like.INF do.1sG I you for along time nicht mehr mögen .

not anymore

'I still love you but I stopped liking you a long time ago.' (http://www.neon.de/ artikel/fuehlen/liebe/am-ende-bleibt-nur-das-vermissen/1013639, access: 02.08.2017)

\subsubsection{Semantically empty host II: Verb doubling}

A peculiar variant of VP-topicalization is found in a number of German dialects. In contrast to VP-topicalization with tun-insertion, the fronted infinitive is accompanied by the finite form of the same lexical verb in V2-position, as illustrated in (28). Fleischer (2008) call this construction topikalisierende Infinitivverdoppelung 'topicalizing infinitive doubling'.

(28) a. VP-topicalization with verb doubling (NON-STANDARD GERMAN)

Trink-en trink-t er nicht, aber rauch-en rauch-t er. drink-INF drink-3sg he not but smoke-INF smoke-3sg he 'He doesn't drink but he smokes.' (Fleischer 2008: 247-248)

b. VP-topicalization with tun-insertion (STANDARD GERMAN) Trink-en tu-t er nicht, aber rauch-en tu-t er. drink-INF do-3sg he not but smoke-INF do-3sg he 'He doesn't drink but he smokes.'

b. Verum focus

Ich TU ja schreiben.

I do.1SG PRT write.INF

'I do write.'

(Abraham \& Fischer 1998: 41 nach Eroms 1984)

(ii) * Der Junge tut ja einen guten Charakter besitzten. the boy do.3Sg PRT a good character own. 'The boy does have a good character.' 
Note that modals, auxiliaries, and periphrastic tun allow the embedding of infinitives. These infinitives may be lexically identical to the embedding predicate, as in (29a). Accordingly, such self-embedding leads to patterns that are superficially very similar to cases of verb doubling. Self-embedding can, however, be differentiated by examples like (29b), which show that it may also appear in a V-final clause. In contrast, the doubled verbs in (28a), trinken 'drink' and rauchen 'rauchen' do not allow embedding of infinitives at all. Thus, verb doubling does not occur in clause-final position.

a. Könn-en kann er, aber woll-en will er nicht. can-INF can.3sg he but want-INF want.3sg he not 'He could be able to do it but he is not willing to want to do it.' (Fleischer 2008: 246)

b. Es ist doch klar, dass ein Kind in dem Alter das noch nicht könn-en It is PART clear that a child in this age that yet not can-INF kann.

can.3sG

'It is obvious that a child of this age cannot be able to do this.'

In his detailed survey, Fleischer (2008) reports that this construction was spread over the German language area: The northern end consists of the Berlin dialect as well as archaic peripheral varieties of Prussian. On the southern end it is attested in High Alemannic of Grisons (Switzerland), where it seems to be restricted to auxiliaries, mostly be, as in (33) (see also Glaser \& Frey 2007). Additionally, the phenomenon is attested in several diasporic German minority dialects, which have survived in the former Soviet Union. ${ }^{12}$

The use of the VP-topicalization with verb doubling is the same as with tuninsertion. Fleischer (2008) states that verb doubling is functionally equivalent to tun-insertion, i. e. it is assigning a special information structural status to the

12 Koopman (1984: 37-38, 151-186) describes a very similar phenomenon under the term predicate cleft construction. She notes that this construction can be found in many African languages and many Caribbean creoles (Koopman 1984: 154). In the Kru lanaguage Vata, for example the verb gets focused by placing it in clause-initial position. Crucially, a copy of the verb is present in its unmarked position within the clause, as shown in (i). Note that the fronted verb may appear in the imperfective form $l \bar{e}$, as in (i.a), or in the base form $l \bar{i}$, as in (i.b), but never in the perfective form $l i$, as in (i.c). This parallels the verb doubling cases: In the left periphery only a base form is required, which represents the lexical meaning of the verb. The lower copy is the host for the phi-features. Note further that in Vata, too, only one of the verb forms can be semantically active because 'eat' does not embed clausal units, i. e. the predicate cleft construction is independent of the argument structure of the verb involved (Koopman 1984: 157). 
fronted VP. This is further supported by examples that show both forms contrasting in one sentence, as in (30).

(30) a. PRUSSIAN

Schnuw-e schneff-t he nech, aber preem-e dei-t he

Schnupf-en schnupf-t er nicht aber priem-en tu-t er

snuff-INF snuff-3sg he not but chew tobacco-INF do-3sg he

färchterlich.

fürchterlich.

horribly

'He doesn't snuff but he chews tobacco horribly.'

b. Issime (High AllemanNic)

Tringe tringt=er nöid, wa röike tut=er.

trinken trinkt=er nicht, aber rauchen tut $=\mathrm{er}$

drink.INF drinks=he not but smoke.INF does=he

'He doesn't drink but he smokes.'

(Fleischer 2008: 252)

In Yiddish, a V2-language with partial German origin, verb doubling is attested too. As can be seen in (31a), only the verb or larger parts of the VP may be topicalized, as in (31b).

(i) VATA
a. lè à le sáká
eat we eat rice
'We are really EATING rice.' or 'We are eating rice.'
b. lī ó dā sákálì
eat she/he AUX.PERF rice eat
'She/He has EATEN rice.'
c. lì ó lì sáká
eat she/he ate rice
'She/He ATE rice.'
(Koopman 1984: 38)

Katja Jasinskaja (p.c.) pointed out that verb doubling constructions are also common in Slavic languages (see Karagjosova \& Jasinskaja 2015 and references therein) and crosslingustically, their presence may be rather the rule than the exception (see also Jouitteau 2012: 155-157 and references therein). 
(31) YIDDISH
a. Ess-en es-t Maks fish. eat-INF eat-3sG Max fish 'As for eating, Max eats fish'
b. [Ess-en fish] es-t Maks. eat-INF fish eat-3sg Max 'As for eating fish, Max eats them'

(Cable 2004: 2)

Yiddish also exhibits a particular phenomenon that sheds light on the mechanism underlying the doubling mechanism. For verbs whose paradigm involves suppletive forms or ablaut, the topicalized infinitive may be realized as a pseudoinfinitive, which consists of the stem variant of the inflected form to which the infinitive suffix is added, as illustrated in (32) (Fleischer 2008: 260-261).

(32) YIDDISH

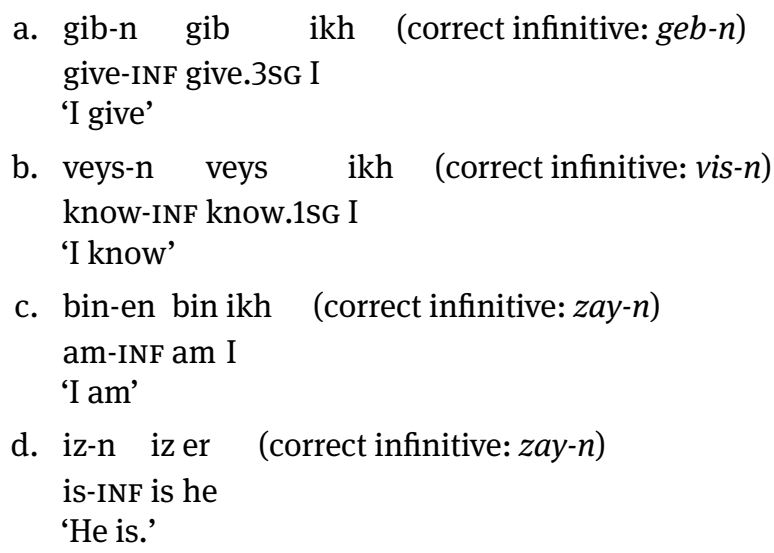

(Fleischer 2008: 260)

These pseudo-infinitives indicate that the source of the fronted infinitive is the finite verb from the V/I position. As I have exemplified in (26), the verb stem moves to Spec-CP, where the infinitive suffix is added. Somehow certain languages seem to apply a filter that excludes illicit infinitives, as shown in (33), whereas Yiddish seems to lack such a smoothing device.

(33) Alemannic

a. Syn bischt schoon albig der glych verdamt Schelm! be.INF be.2SG still always the same damned rogue 'You are still the same old rogue!' (Fleischer 2008: 248) (area: Splügen, Davos) 
b. Sii bisch scho en Flissige. be.INF be.2sG certainly a hard working 'You certainly work hard.' (Glaser \& Frey 2007: 5) (area: Grisons)

The inevitable conclusion from verb doubling in the context of VP-topicalization is that the finite verb in the V2-position is a semantically empty copy which is inserted only to enable the spell-out of the finiteness features in $\mathrm{C}$ in order to satisfy the V2-requirement. Let's recapitulate the arguments: First, both copies of the verb cannot be semantically active because verb doubling does apply to verbs that do not allow the embedding of (bare) infinitives. Second, the topicalized phrase must not be semantically empty, otherwise the topic of the sentence would be empty. Third, the finite verb in V2-position can be replaced by an inserted tun, by modals, or auxiliaries, whereas the topicalized verb has to be proper lexicalized. Forth, Yiddish pseudo-infinitives provide empirical support for the assumption that the topicalized infinitive is the dislocated finite verb. In sum, the verb doubling phenomenon indicates that the V2-position must only be filled with finiteness features. This may be achieved by inserting semantically empty copies of the verb to provide a host for the relevant features. Thus, this adds further support to the V2-Reconstruction Hypothesis by indicating that the V2-requirement does not involve targeting a meaningful verbal element. Consequently, it is predicted that verb doubling cannot occur in the verb's base position, i. e. the position in which the semantics of the verb is active, such as the clause-final position in (34). This prediction is borne out because such cases seem to be non-existent (Bayer \& Freitag 2020: 88).

\section{(34) GERMAN}

*Ich glaube, dass ihm das nichts schaden schadet.

I believe that him this nothing harm harms

'I believe that it doesn't harm him'. (Bayer \& Freitag 2020: 88)

A somewhat comparable phenomenon are dummy auxiliaries, which are observed in L2-acquisition, shown in (35). They also seem to be semantically empty elements that are inserted in C. In contrast to verb doubling, dummy auxiliaries are only quasi-finite elements that do not show proper subject agreement.

\section{a. L2 GERMAN}

Ein Junge is die Fußball spielen.

a boy is the football play.INF

'A boy is playing (with the) football.' (L1 Turkish, ca. 6 years) (Haberzettl 2003: 45) 
b. L2 DUTCH

Zij is ligt in de boot

she is.3sg lies.3sg in the boat

'She is lying in the boat.' (L1 Turkish) (van de Craats 2009: 77)

These patterns seem to appear more frequent in L2 Dutch (Coenen \& Klein 1992, Verhagen 2009: 58-62, van de Craats 2009) but are also reported for L2 German (Haberzettl 2003, Chilla et al. 2013).

\subsubsection{Semantically empty host III: Frisian wer-insertion}

In another West Germanic variety, we find additional evidence which indicates that the lexical content of the verb does not need to appear in the C-domain but only the finiteness features. Karrharde North Frisian ${ }^{13}$ exhibits a periphrastic verb construction with a finite auxiliary wer- in V2-position and a thematic verb in base position. Like the tun-periphrasis, this construction appears in declaratives, whinterrogative, polar interrogatives, and imperatives, as shown in (36). Moreover, this construction does generally not appear with other auxiliaries or modals. In contrast to the tun-periphrasis, the thematic verb in clause-final position is finite too. According to Hoekstra (2016), wer- insertion does not show semantic or pragmatic restrictions on the co-occurring verb classes. The syntactic distribution of wer-, however, is restricted to the V2-position. It never occurs in clause-final position. Hoekstra (2016) argues that wer- is not of verbal origin but stems from the interrogative complementizer wer 'if, whether'. The assumption that wer- is a reanalyzed complementizer that functions as a semantically empty auxiliary does account for all its properties: restriction to V2-position (C-position), complementary distribution with other auxiliaries in V2-position, no semantic/pragmatic restriction, and the double marking of finiteness on the auxiliary and the thematic verb. Due to its origin as a finite complementizer, wer- selects a finite VP, even in last resort cases, such as VP-topicalization in (37), whereas German tun selects a non-finite VP. Hoekstra (2016) calls the phenomenon finite verb doubling what I consider to be a misnomer for the following reasons: The only thing that appears twice is the finiteness morpheme. The thematic verb, however, appears only once, in contrast to real doubling of the verb stem as described in the previous section. Furthermore, wer- is actually not of verbal origin, which is (presumably) the crucial prerequisite for the double marking of finiteness.

13 Frisian is closely related to low German and Dutch. It is a V-final V2-language that is spoken in the coastal area of the German Bight. 
(36) KARRHARDE NORTH FRISIAN

a. Tèth-üttīnen wer-t er kan-d.

Teeth-pulling WER-PRS.3SG he know-PRS.3SG

'He knows how to pull teeth.' (Hoekstra 2016: 322)

b. Wat wer-e jem der apfask-e?

what WER-PRS.2PL you there up.fish-PRS.2PL

'What are you fishing up there?' (Hoekstra 2016: 323)

c. Denn wer-e man eg aw’t Håd fāl-e.

then WER-IMP.PL only not on=the head fall-IMP.PL

'Then don't fall on your head.' (Hoekstra 2016: 325)

(37) KARRHARDE NORTH FRISIAN

He es fallight ferkimen, an lait je sagt wer krōnk, he is maybe come down and lays really perhaps somewhere ill an $\quad[\mathrm{VP} \text { sturwe-d] }]_{1}$ wer-t ham niman $t_{1}$.

and nurses-PRS.3SG WER-PRS.3SG him no one

'Maybe he has come down in the world and is perhaps ill in bed somewhere with nobody nursing him.' (Hoekstra 2016: 341)

Frisian wer-insertion therefore shows that the V2-position does not have to be filled with a genuinely verbal element. A suitable host for the inflectional affix appears to be sufficient. This fact agrees perfectly with the results of periphrastic tun and verb doubling.

\subsubsection{Complementizer Agreement: Inflection on non-verbal C-elements}

Another configuration, the so-called complementizer agreement, can be observed in embedded clauses of German and Dutch dialects. As with Frisian wer-insertion, the inflectional affix appears at the clause-final verb and on C-elements, i.e. complementizers and wh-pronouns as illustrated in (38). ${ }^{14}$ Crucially, the subject agreement does not replace the verbal agreement affixes but appears additionally (Bayer 1984, Bennis \& Haegeman 1984).

14 This phenomenon therefore has to be distinguished from other instances of complementizer agreement. Kawasha (2007) for example describes a phenomenon in Bantu languages in which complementizers agree in person and noun class with the subject of the matrix clause. Furthermore, superficially similar phenomena in non-V2 languages differ considerably. Complementizer agreement in Nadji Arabic, as discussed in Lewis Jr. (2013), occurs only on specific lexical items, is optional, and uses non-verbal agreement morphemes. 
(38) BAVARIAN

I frog' me, ob-sd ned du des mocha kan-sd.

I ask myself, whether-2sG not you this make could-2sG

'I ask myself, whether you could not do this.' (Weiss 2005: 148)

The geographical distribution seems to be restricted to Continental West Germanic languages, i. e. varieties of German and Dutch. Most prominently, this phenomenon has been described for Bavarian (Bayer 1984), West Flemish (Haegeman 1992, Shlonsky 1994), and Frisian (de Haan 2010). Weiss (2005: 149-153) notes that in most dialectal variants (of German and Dutch) at least some kind of complementizer agreement can be observed even though there are dialects that lack this phenomenon entirely (see also Zwart 1993, Hoekstra \& Smits 1998). The V2property is commonly assumed to be a necessary prerequisite for complementizer agreement. Nevertheless, being a V2-language does not seem to be a sufficient condition because complementizer agreement has not been reported for Scandinavian languages, North Italian varieties (Rhaeto-Romance), and Kashmiri. ${ }^{15}$

In most dialects, the agreement is paradigmatically defective (see Weiss 2005: 150-152 for an overview). Bavarian and Frisian, for example, display inflectional morphems only for 2nd person singular/plural. West Flemish, on the other hand, shows inflectional markers for all combinations of person and number, and distinguishes even gender in the 3SG (Bennis \& Haegeman 1984: 41). Importantly, inflectional morphemes on the complementizers are restricted to categories of subject agreement (person and number) and never involve any tense features (den Besten 1983: 119). Moreover, complementizer agreement seems to be dependent on the formal marking of agreement on verbs: Hoekstra \& Smits (1998) state that complementizer agreement only shows up for person/number combinations that exhibit the same person/number agreement morpheme in present and preterite forms of auxiliaries. This condition accounts for paradigmatic gaps of the individual dialectal variants.

Despite the term complementizer agreement, the inflectional affixes do not exclusively combine with complementizers but with the lowest element in the left periphery (Bayer 1984: 235). These might be complementizers, such as dass 'that'

15 It must be noted, however, that some North Italian dialects, such as Cimbrian, show subject clitics at complementizers that introduce non-V2 clauses whereas enclisis is blocked in subordinate clauses with V2-order (Bidese et al. 2012, 2013). Kashmiri exhibits V2-order in most types of embedded clauses, which therefore are incompatible with complementizer agreement. 
in (39a), wenn 'if' and weil 'because'. In absence of an overt complementizer, the affix may also attach to a wh-element, as shown in (39b) and (39c). ${ }^{16}$

(39) BAVARIAN

a. Du sollst song an wäichan Schua dass-st du wui-st you should say a which one shoe that-2sG you want-2sG 'You should say which one of the shoes you want.' (Bayer 1984: 235)

b. Du sollst song wann-st du komm-st you should say when-2sG you come-2sG 'You should say when you are going to come.'

c. I frog' me, warum-sd des ned moch-sd. I ask myself, why-2sG this not make-2sG 'I ask myself why do you not do this.' (Weiss 2005: 148)

The relation of complementizer agreement and V2-movement can be captured by two generalizations: First, complementizer agreement is not optional but obligatory in dialects that allow it. ${ }^{17}$ Second, complementizer agreement and verb movement are complementary distributed. The following examples from Bavarian with the causal complementizer weil 'because' illustrate the complementary distribution of inflectional morpheme and verb movement. If the complementizer is inflected for 2nd person, as in (40a), V2-order is impossible. With a non-inflected complementizer, as in (40b), verb movement is required.

(40) BAVARIAN

a. Des is schood, weil-st du 〈bist〉 gestern a scho That is disappointing because-2sG you are yesterday also already nit kemma $\langle$ bist $\rangle$.

not come are

'That is disappointing since you already didn't show up yesterday.'

b. Des is schood, weil du 〈bist〉 gestern a scho nit That is disappointing because you are yesterday also already not kemma 〈^bist〉.

come are

'That is disappointing since you already didn't show up yesterday.'

16 Bayer (2014: 41-44) states that only word-size wh-operators receive inflection suffixes. In case of phrasal wh-elements, insertion of the default complementizer dass 'that', as in (39a) provides a licit host for the inflectional morpheme.

17 To my knowledge only Bayer (2014: 41) states explicitly that the complementizer agreement is obligatory in Bavarian. The same can (only) be inferred for the other dialects. 
Even though we may assume that complementizer agreement originates from subject clitics, two properties distinguish them robustly: First, clitics are never obligatory whereas complementizer agreement is. Second, clitics do not double, whereas complementizer agreement usually cooccurs with overt subjects (Bayer 2014: 41-43), as shown in (39a) and (39b).

It is still debated whether complementizer agreement involves some kind of copy mechanism of the T-head's phi-features onto C (Fuß 2014), or whether it expresses a separate agreement relation between C (Fin) and the subject (Carstens 2003, Haegeman \& van Koppen 2012). One observation, however, indicates that complementizer agreement cannot involve a simple copy mechanism of the verbal affix onto the complementizer. Some East Netherlandic dialects and Brabants show non-identical agreement morphemes on the complementizer and the verb (Zwart 1993, Hoekstra \& Smits 1998), as illustrated by the contrasting morphemes $-(d) e$ and $-t$ in (41).

a. EAST NeTHERLANDiC

... datt-e wij speul-t. that-1PL we play-1PL

'... that we play.'

b. BRABANTS

... dad-de gullie kom-t. that-2PL you come-2PL

'... that you come.'

(Zwart 1993: 253)

Interestingly, the distribution of these two morphemes ${ }^{18}$ is not lexically specified. The examples in (42) and (43) show that both endings might appear on the verb. In non-subject-initial V2 matrix clauses, the finite verb in V2-position in (42a) and (43a) shows the same agreement morpheme $(-e /-d e)$ as the complementizers in the subordinate clauses in (41). In subject-initial V2 matrix clauses, as in (42b) and (43b), however, the inflectional morpheme is invariably $-t$, like on the clause-final verb in subordinate clauses in (41).

EAST NETHERLANDIC

a. Waar speul-e/*-t wij? where play-1PL we 'Where do we play?'

18 As long as we cannot specify any additional semantic contribution to the element in C, I assume that the $\mathrm{C}$-inflection morpheme is an allomorph of the V-inflection morpheme. However, since the $\mathrm{C}$-domain is a functional domain, we might expect some abstract semantic contribution to be there. 
b. Wij speult-t/*-e. we play-1PL 'We play.'

(Zwart 1993: 254)

(43) BRABANTS

a. Waneer kom-de/*-t gullie?

when come-1PL you

'When do you come?'

b. Gullie kom-t/*-de. you come-1PL 'You are coming.'

(Zwart 1993: 254)

A similar dual agreement morpheme system is also found in Lower Bavarian for first person plural only (-ma vs. $-n$ ), as in (44a). In contrast to the Dutch variants above, the V2-verb exhibits the agreement morpheme of the complementizers $(-m a)$ in both non-subject-initial clauses and subject-initial clauses, as shown in (44b) and (44c).

(44) LOWER BAVARIAN

a. ... dass-ma mir noch Minga fahr-n/^-ma. that-1PL we to Munich drive-1PL '... that we drive to Munich.'

b. Fahr-ma/^-n mir noch Minga? drive-1PL we to Munich 'Do we drive to Munich?'

c. Mir fahr-ma/* $-n$ noch Minga. we drive-1PL to Munich 'We drive to Munich.'

(Bayer 1984: 251, Weiss 2005: 153-154)

Consequently, it is not evident what the contrast of the inflectional morphemes in East Netherlandic and Brabant indicate, given that we assume a basically identical syntactic structure as in Bavarian.

I interpret the inflectional morphemes on the complementizer as spell-out of the finiteness features of the verb, or more precisely the subset of subjectagreement features. The complementary distribution of complementizer agreement and V2-movement suggests that both satisfy the same requirement, i. e. the requirement for phi-features in the $\mathrm{C}$-domain. Complementizer agreement shows 
that checking the phi-features in $\mathrm{C}$ does not have to be realized by verb movement: If the C-head is filled by a suitable host for the agreement features, verb movement is suspended. Thus, this observation provides further support for the V2-Reconstruction Hypothesis: V2-movement is not related to the meaning of the verb but only the phi-features of the finite verb are attracted and the lexical part of the verb is pied-piped.

\subsubsection{Summary: Only agreement features in C}

In this section, I have discussed four phenomena which illustrate that V2-movement is a semantics-free operation in the sense that the lexical content of the verb is not interpreted in $\mathrm{C}$. The discussion of particle verbs revealed that V2-movement actually targets sub-semantic units, namely prosodic words. For reasons of economy, only the smallest part that can carry the finiteness feature moves to $\mathrm{C}$, which is the prosodic word in case of particle verbs. The following three subsections illustrated alternative solutions for how semantically empty hosts for the agreement features can be provided if the lexical verb is not available, for example because of verb topicalization. One possibility is the insertion of a generalized, semantically empty dummy verb, such as the German tun 'do'. The second option is the doubling of the lexical verb. Crucially, those elements are only a host for the verbal agreement in C, as evidenced by their semantic emptiness: In the C-position, these elements do not contribute their lexical meaning component and do not require that their argument frame must be satisfied. A third option is the insertion of the complementizer-like Frisian wer. In sum, these C-elements can be characterized as PF-related hosts for the verbal agreement features which have to be realized in the C-position, but due to their affixal nature (bound morphemes) they cannot appear in $\mathrm{C}$ on their own. ${ }^{19}$ The last phenomenon, complementizer agreement, shed

19 This correctly predicts that languages which encode finiteness not by affixes do not show movement of lexical verbs. This is the case in the finiteness second language Warlpiri as described by (Hale 1983), in which finiteness is obviously morphologically disconnected from the verb. The 2nd position is taken by finiteness morphology whereas the verb can be elsewhere, as shown in (i). Legate (2008) argues that the aspect and agreement markers in Warlpiri are (second position) clitics which attach either to auxiliaries or complementizers.

(i) Ngajulu-rlu ka-rna-ngku nyuntu nya-nyi

I-ERG PRS-1SUB-2OBJ you see-NON.PST

'I see you' (Hale 1983: 18)

Tohono O'odham (Papago) is another finiteness second language in which the finiteness marking is always realized as an auxiliary in second position and never through inflectional affixes on 
more light on that observation. In a suitable environment, the verb does not move at all. In presence of a complementizer, as in subordinate clauses, the verbal inflection appears at the complementizers, i. e. in C, without displacing the verb. In these cases the finiteness features are present on both, the $\mathrm{C}$-head and the V-head. It became evident that the relevant part of the finiteness inflection is only the subject agreement, which must be realized at the C-head.

\subsection{The base position: Arguments for the necessity of reconstruction}

This section concentrates on the second claim of the V2-Reconstruction Hypothesis, namely that the finite verb is obligatorily interpreted in its base position. This is obviously true in V-final clauses. I will argue that, in V2-clauses, the finite verb obligatorily has to be reconstructed into its base position in order to be interpreted correctly with respect to the scope of semantic operators, such as focus-sensitive operators (Section 3.3.1), NPI-licensors (Section 3.3.2), and sentential negation (Section 3.3.3).

\subsubsection{Association with focus}

A first diagnostic which shows that the finite verb must be interpreted in the base position is association with focus. Semantic operators operate on elements in their scope domain. Focus-sensitive operators do even interact with the focusbackground structure within their arguments. Focus particles such as nur 'only', lediglich 'solely', and negative constrastive construction (Drubig 1994: 28-37) are examples for such an association with focus, as shown in (45). Crucially, the truth conditions of the sentences change as a function of the associated focus phrase of the focus-sensitive operator, as indicated by the focus alternatives in brackets.

(45) a. dass das Kind nur [eine kleine Cóla ${ }_{\mathrm{Foc}}$ getrunken hat]. that the child only a small Coke drunk has 'that the child only drank a small Cóke (and not a beer).'

b. dass das Kind nur [eine kleíne ${ }_{\mathrm{Foc}}$ Cola getrunken hat]. that the child only a small Coke drunk has 'that the child only drank a smáll Coke (and not a large one).'

the lexical verb. Consequently in O'odham, the lexical verb never occupies the second position (Zepeda 1983, Miyashita 2006). 
c. dass das Kind lediglich [eine kleine Cola bestéllt $\mathrm{FOC}_{\mathrm{FC}}$ hat]. that the child solely a small Coke ordered has 'that the child only órdered a small Coke (she didn't drink it).'

d. dass das Kind nicht [die kleíne ${ }_{\text {Foc }}$ Cola getrunken hat]. that the child not the small Coke drunk has 'That the child didn't drink the smáll Coke (but the large one).'

It is still debated how the mechanics of association with focus work in detail (see e. g. Krifka 2006 and Wagner 2006). It is, however, widely accepted that a basic requirement is that the focus-sensitive operator must have scope over the focus, i. e. the operator must c-command the focus constituent (Rooth 1985: 40, König 1993: 985, Bayer 1996: 15, Büring \& Hartmann 2001: 237, Krifka 2007: 27).

If the focused constituent is moved to the prefield, the focus particle can be moved along with it, as shown in (46). In this way the c-command requirement remains satisfied.

(46) a. [Nur [der Doktoránd $\left.]_{\mathrm{FoC}}\right]$ hat nur der Doktorand die Arbeit geschrieben only the $\mathrm{PhD}$ candidate has the thesis written

hat.

'Only the PhD candidate has written the thesis.'

b. [Nur [die Arbeit $]_{\mathrm{FoC}}$ ] hat der Doktorand nur die Arbeit geschrieben only the thesis has the $\mathrm{PhD}$ candidate written

hat.

'The $\mathrm{PhD}$ candidate has written only the thesis.'

c. [Nur geschríeben ${ }_{\text {Fос }}$ ] hat der Doktorand die Arbeit nur geschrieben only written has the $\mathrm{PhD}$ candidate the thesis

hat.

'The PhD candidate has only written the thesis.'

Because c-command commonly implies precedence, the focus particle usually precedes the focus constituent. Under certain conditions, however, the order of focus particle and focus constituent can be reversed, as shown in (47). Crucially, the inverted order leads to marked constructions that receive an emphatic exclamative flavor or are even judged as unacceptable (e. g. Büring \& Hartmann 2001: 240). Jacobs (1983: 95-101) adds two more observations regarding the markedness of postfocal particles: First, the productivity of this pattern is lexically restricted, i. e. it is, for example, acceptable with nur 'only' but ungrammatical with lediglich 'solely', as shown in (47b) vs. (47c). Second, even for particles that allow the inverted order, it occurs preferably in the prefield. In the middle field it needs stronger intonational means (accent, pause) to avoid an association with subsequent constituents, as in (47d-47e). 
(47) (The superscript ${ }^{\mathrm{M}}$ indicates the marked character of the sentence.)

a. ${ }^{\mathrm{M}}\left[\right.$ Geschríeben $\left._{\mathrm{FoC}}\right]$ hat der Doktorand die Arbeit nur geschrieben written has the $\mathrm{PhD}$ candidate the thesis only

hat.

b. ${ }^{\mathrm{M}}\left[[\text { Der Doktoránd }]_{\mathrm{FOC}}\right.$ nur $]$ hat der Doktorand nur die Arbeit geschrieben the $\mathrm{PhD}$ candidate only has the thesis written

hat.

c. * $\left[[\text { Der Doktoránd }]_{\mathrm{Foc}}\right.$ lediglich $]$ hat der Doktorand nur die Arbeit the $\mathrm{PhD}$ candidate solely has the thesis geschrieben hat. written

d. ${ }^{\mathrm{M}}$ [Der Doktoránd $]_{\mathrm{FOC}}$ hat [nur der Doktorand] die Arbeit geschrieben the $\mathrm{PhD}$ candidate has only the thesis written hat.

e. ${ }^{\mathrm{M}}$... dass [[der Doktoránd $]_{\mathrm{FOC}}$ nur] die Arbeit geschrieben hat. that the $\mathrm{PhD}$ candidate only the thesis written has

If the inverted order of focus particle and focus constituent is caused by V2movement, however, no markedness is induced, as illustrated in (48b) (Büring \& Hartmann 2001: 241, fn.9). Note also that no lexical restrictions are observable, as it was the case for the marked inverse order above. ${ }^{20}$

a. Wir sahen, dass der Hund sich nur/ lediglich verteídigte ${ }_{\mathrm{Foc}}$. we saw that the dog REFL only solely defended 'We saw that the dog did only defend itself (it didn't attack those guys).'

b. Der Hund verteídigte ${ }_{\mathrm{FOC}}$ sich nur/ lediglich werteidigte. the dog defended REFL only solely 'The dog did only defend itself (it didn't attack those guys).'

This apparent irregularity is readily explained by the V2-Reconstruction Hypothesis. From the perspective of interpretation, only the finiteness features move to second position whereas the focused verb is only interpreted in its clause-final base position, in which it is c-commanded by the focus particle. At LF, the structure in (48b) actually looks like (49).

(49) Der Hund -te sich nur verteídig ${ }_{\text {Foc }}$ te the dog 3SG.PST REFL only defend

20 This indicates that lediglich 'solely' does not belong to the class of focus-sensitive operators that require a focus exponent in its surface scope, as described for mehr als 'more than' in Section 2.1.3.1. 
In sum, the investigation of association with focus indicates that finite verbs in V2clauses are interpreted only in their base position: Derived word order, in which the focused constituent is outside of the c-command domain of the focus sensitive operator, leads to a strong markedness. This markedness is absent if a focused verb is moved outside the c-command domain of a focus sensitive operator by V2movement. Hence, I conclude that V2-moved finite verbs are only interpreted in their clause-final base position. In this position, the verb is within the c-command domain of the focus-sensitive operator.

\subsubsection{Verbal negative polarity items: Only licensed in the base position}

A similar argument can be constructed for negative polarity items. Polarity items are linguistic elements whose interpretation and grammaticality is dependent on the polarity of their minimal syntactic environment, for simplicity, the minimal clause in which they occur. This is illustrated for the negative polarity item (NPI) jemals 'ever' in (50a) and the positive polarity item (PPI) durchaus 'certainly' in (50b). The NPI is only grammatical with the negative subject niemand 'nobody' whereas the pattern is exactly the opposite for the PPI. The translations indicate that the same contrast is also observed for the English equivalents.

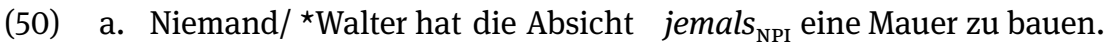
nobody Walter has the intention ever a wall to build 'Nobody ever ${ }_{\text {NPI }}$ intended to build a wall.'/“*Walter ever ${ }_{\text {NPI }}$ intended to build a wall.'

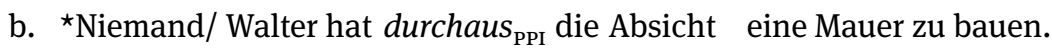
nobody Walter has certainly the intention a wall to build ‘`Nobody certainly ${ }_{\mathrm{PPI}}$ intended to build a wall.'/'Walter certainly ${ }_{\mathrm{PPI}}$ intended to build a wall.'

Despite the term negative, NPIs are not only licensed by anti-additive operators, such as negation, but also by downward-entailing operators such as few and hardly, in interrogative clauses, in antecedents of conditional clauses, and in complement clauses of adversative predicates such as doubt or refuse (Progovac 1994, Richter \& Radó 2014). ${ }^{21}$

21 NPIs can be divided into strong NPIs, which need to be licensed by anti-additive operators (negation), and weak NPIs, which are also licensed by downward entailing operators. I will not elaborate on this distinction because it bears no relevance for the present argument. For a detailed discussion and experimental confirmation of the licensing requirements of strong and weak NPIs see Richter \& Radó (2014). 
Progovac (1994) proposes to analyze polarity items with the principles of the binding theory. Negative polarity items resemble reflexives such that both are dependent: NPIs must be in the scope of an appropriate licensor, as reflexives must be bound by their antecedent. Positive polarity items and pronouns, on the other hand, are anti-dependent: PPIs must be interpreted outside of the scope domain of a downward entailing operator (or the particular clause types which have been mentioned above) as pronouns must be interpreted outside of the scope domain of their local antecedents. The configurations of the licensing requirements/ restrictions are illustrated in (51).

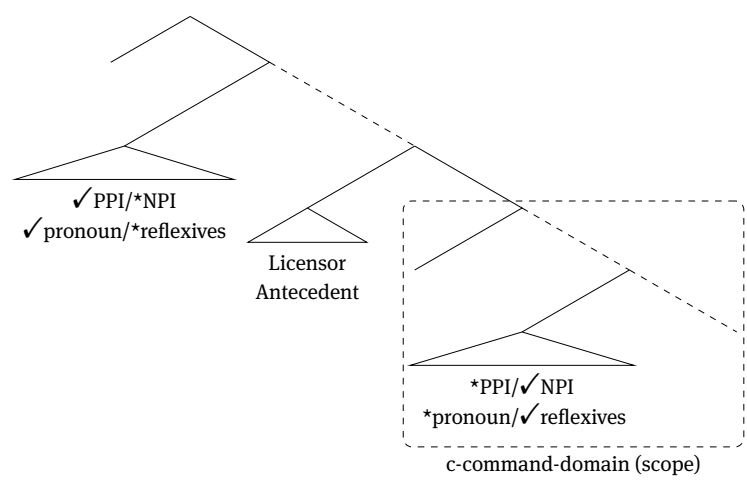

Adverbial NPIs in German indicate that NPI-licensing has to be satisfied at the surface structure. Adverbial NPIs cannot move out of the c-command domain of their licensor, as illustrated by the contrast between (52) and (53). Even though adverbials can normally be placed freely into the prefield, illustrated by sicherlich, gestern, and oftmals in (52), fronting of adverbial NPIs results in ungrammaticality, as shown in (53). ${ }^{22}$

(52) a. Sicherlich hat niemand LIC jemals $_{\text {NPI }}$ eine Mauer zu bauen beabsichtigt. certainly has nobody ever a wall to build planned 'Certainly, nobody ever planned to build a wall.'

b. Gestern haben [nur wenige $]_{\text {LIC }}$ überhaupt $_{\text {NPI }}$ mitgemacht. yesterday have only few at all participated 'Yesterday, only few have at all participated.'

22 Note that überhaupt can be used as a clausal linker in the sense of 'actually/generally'. Under that reading, sentence (53b) is grammatical but überhaupt is a different lexical item and not an NPI. 
c. Oftmals hat [kein Student $]_{\mathrm{LIC}}$ [auch nur ein bisschen $]_{\mathrm{NPI}}$ gelernt. oftentimes has no student also only a bit studied 'Oftentimes, no student has learned only a tiny bit.'

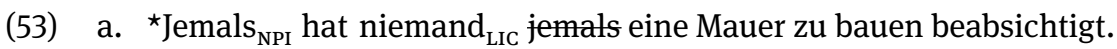
ever has nobody a wall to build planned

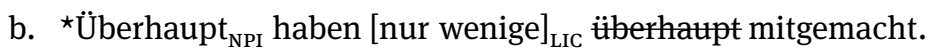
at all have only few studied

c. $*[\text { Auch nur ein bisschen }]_{\mathrm{NPI}}$ hat [kein Student $]_{\mathrm{LIC}}$ auch nur ein bisschen also onlya bit hasno student gelernt. studied

There are two exceptions to this ban on movement, in which an NPI can be fronted: First, the NPI may be contained in a larger constituent that presumably undergoes reconstruction into its base position and thereby restores the licensing relation, as in (54), see also Meinunger (2004: 54).

(54) a. [Jemals ${ }_{\mathrm{NPI}}$ eine Mauer zu bauen $]_{\mathrm{VP}}$ hat niemand $\mathrm{LIC}_{\mathrm{LC}}$ jemals eine Mauer $\mathrm{zu}$ ever a wall to build has nobody

bauen beabsichtigt.

planned

'Nobody ever planned to build a wall.'

b. [Überhaupt $t_{\mathrm{NPI}}$ nur eine Prüfung $]_{\mathrm{NP}}$ haben [nur wenige Studenten $]_{\mathrm{LIC}}$ at all only one exam have only few students

überhaupt nur ein Prüfung bestanden.

passed

'Only a few students have passed even one exam.'

c. $\left[\text { Auch nur }{ }_{\mathrm{NPI}} \text { eine Frage }\right]_{\mathrm{NP}}$ hat [kein Student $]_{\mathrm{LIC}}$ auch nur eine Frage also only one question has no student

beantwortet.

answered

'No student has answered even one question.'

The second option is lexically and morphologically very restricted: Some NPIs can combine with their licensor on the morphological level. Similar to other German indefinites, where we observe that nicht 'not' and ein 'a' combine to kein 'no', or nicht and jemand 'someone' combine to niemand 'no one', I assume that nicht 
and jemals 'ever' combine to niemals. ${ }^{23}$ Example (55) illustrates this morphological pied-piping process: In (55a), the subject indefinite combines with the negation and becomes the NPI-licensor. In (55b) the NPI moves to the prefield position, thereby pied-piping the negation. ${ }^{24}$ The complex that ends up in the prefield is a self-satisfying construction that combines both, the element to be licensed and the licensor in one word. ${ }^{25}$

(55) $\varnothing$ hat $\mathrm{NEG}_{\mathrm{LIC}}$ jemand jemals ${ }_{\mathrm{NPI}}$ eine Mauer zu bauen beabsichtigt. has NEG somebody ever a wall to build planned

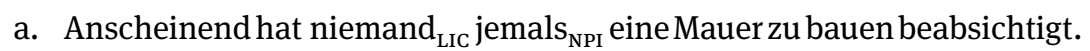
apparently hasnobody ever a wall to build planned 'Apparently, nobody ever planned to build a wall.'

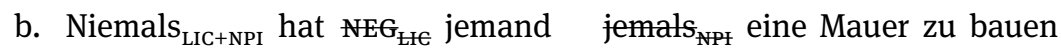
Never has somebody a wall to build beabsichtigt. planned 'Never did anyone plan to build a wall.'

With this background on NPIs, we now inspect the exceptional German verb brauchen 'need'. Despite its transitive use, brauchen also functions as a modal

23 Penka (2011) provides arguments for the separation of the negation and the indefinite meaning, even though her view on the lexical and syntactic analysis of these elements differs from the present one.

24 It is always the highest (leftmost) indefinite that combines with the negation. The negation probably marks the right edge of the existential closure domain because, if an indefinite precedes the negation, it receives an existential interpretation, as in (i), see Diesing (1992) for more on this.

(i) a. Wahrscheinlich hat niemand die Blumen gegossen. probably has no one the flowers watered 'It's possible that no one watered the flowers.'

b. Wahrscheinlich hat jemand die Blumen nicht gegossen. probably has someone the flowers not watered 'It's possible that a specific person whose name I will not say, has not watered the flowers.'

25 Note that these cases resemble the examples in (46) where the focus sensitive operators move with the focus constituent to the prefield. 
verb on a par with müssen 'must', where it has the meaning 'need to/be obliged to'. ${ }^{26}$ As a modal verb, brauchen is an NPI, as shown in (56). ${ }^{27}$

(56) Er weiß, dass er dem Studenten ${ }^{\star}\left(\right.$ nicht $\left._{\mathrm{LIC}}\right) \mathrm{zu}$ drohen braucht $_{\mathrm{NPI}}$. he knows that he [the student].DAT not to threaten needs 'He knows that he doesn't need to threaten the student.'

In V2-clauses, such as (57), brauchen appears in second position, where it precedes the negation. In this constellation, the NPI brauchen is outside of the ccommand domain of its licensor nicht. It is obvious that brauchen, in (57), does not employ one of the above mentioned exceptions: It has not been moved to $\mathrm{C}$ as part of a larger constituent and it does not morphologically combine with its licensor. The NPI brauchen, therefore, seems to be the only NPI that can violate its licensing condition.

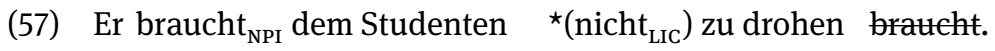

he needs [the student].DAT not to threaten

'He doesn't need to threaten the student.'

The V2-Reconstruction Hypothesis provides a solution to this paradoxical situation. At surface structure (PF), the finite verb moves to second position (C), only to deliver the finiteness feature. The semantic interpretation of the verb, however, takes place in its base position, where it is c-commanded by the NPI-licensor. The finite verb undergoes reconstruction in the same way as the phrasal elements in (54). Hence, no exception to the licensing mechanism of NPIs has to be assumed. The conclusion is that what we see is not what we get at the LF-side of the grammar: At LF, the structure of (57) actually turns out to be as in (58).

(58) Er - $\mathrm{t}$ dem Studenten nicht ${ }_{\mathrm{LIC}} \mathrm{zu}$ drohen brauch $_{\mathrm{NPI}} \mathrm{t}$. he 3SG.PRS [the student].DAT not to threaten need 'He doesn't need to threaten the student.'

26 Barbara Tomaszewicz (p. c.) pointed out that the English modal need (without to) is also an NPI that necessarily scopes under negation to be proper licensed, such that the sentence in (i), only allow the reading in (i.a) but the surface scope order as in (i.b) is not available.

(i) You need ${ }^{*}\left(n^{\prime} t\right)$ shout

a. You don't need to shout. (NEG $>$ MODAL)

b. \# You need to not shout. (MODAL $>N E G)$

27 Dutch exhibits an equivalent NPI modal verb hoeven 'need' (see Lin et al. 2015 and references therein). Because of the extensive similarities between Dutch an German, in particular being V2 and OV-languages, the argument for brauchen is valid for hoeven as well. 
This argument is not restricted to a single lexical item. German exhibits several verbal NPIs. A natural example is given in (59a) and three additional constructed examples in (60). The (un)grammatical alternatives in each case illustrate that the verbs, or rather verb frames, are NPIs.

(59) Raketentests sind Nordkorea per UN-Resolution verboten.

'For North Korea it is forbidden to conduct missile tests by UN-resolution.'

a. Aber das schert ${ }_{\mathrm{NPI}}$ Machthaber Kim Jong-un wenig ${ }_{\text {LIC }} /$ nicht $_{\text {LIC }} /{ }^{\star}$ ein but this bothers potentat Kim Jong-un little not a bisschen $/{ }^{\star} \varnothing$ schert.

bit

'But this bothers potentate Kim Jong-un little/not/a bit/ $\varnothing . '$ [ZDF (TV), Morgenmagazin, 29.08.2017]

(60) a. Zumindest verhehlt $\mathrm{NPI}_{\mathrm{NP}}$ Julius die Verachtung für seinen Vater nicht $\mathrm{LIC}_{\mathrm{C}} /$ at least concealed Julius the contempt for his father not ${ }^{\star}$ schon $/{ }^{\star} \varnothing$ verhelt.

indeed

'At least Julius did(n't) (indeed) conceal the contempt for his father.'

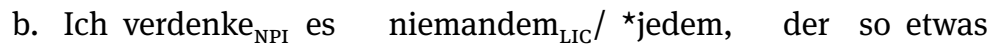
I blame EXPL nobody everybody who so something erlebt hat, werdenke (dass er enttäuscht ist). experienced has that he dissapointed is 'I blame nobody/erverbody who has experienced such things (for being disappointed).'

c. Das vergesse ${ }_{\mathrm{NPI}}$ ich dir nie $\mathrm{LIC}_{\mathrm{LC}} /$ nicht $_{\mathrm{LIC}} /{ }^{*}$ morgen/ ${ }^{\star}$ sicherlich vergesse. that forget I you never not tomorrow certainly 'I will ( $\varnothing /$ forever/certainly) keep that in mind (until tomorrow).'

Most verbal NPIs in German, however, occur in one of two forms that exclude or mask the reconstruction effect: Verbal NPIs of the first type are accompanied by (finite) auxiliaries/modal verbs (mostly idiomatically), which has the effect that the non-finite verbal NPI remains in its base position in V2-clauses, as in (61a). The second type comprises particle verbs where only the inflected stem moves to the V2-position while the particle remains in the clause-final base position, as in (61b). For particle verb NPIs, the argument from Section 3.2.1 becomes relevant: The moved part of the verb must be reconstructed into the base position, next 
to the particle, in order to allow the interpretation of the complex verb and to evaluate the NPI-specific meaning. ${ }^{28}$

(61) a. Trotzdem konnte ich diese Person niemals LIC $/ \star^{*}$ immer schon [ausstehen although could I this person never always stand konnte $]_{\mathrm{NPI}}$.

'Although I could never/*always stand this person.'

b. So komme ich nicht ${ }_{\mathrm{LIC}} /{ }^{\star}$ sehr wohl [umhinkomme $]_{\mathrm{NPI}}$, meine Drohung so come I not very well PRT my threats wahr zu machen. true to make 'So I'm bound to deliver on my threat.'

Summing up, the argument of this section extends the claim of the previous section that verbs must be interpreted in their base position in order to be within the domain of scope taking operators such as negation. Building on the well-known principles of NPI-licensing, I have shown that the German verbal NPIs, such as brauchen, apparently violate this licensing conditions when they have undergone V2-movement. Under the V2-Reconstruction Hypothesis, however, the situation is readily solved because the finite verbal NPI is interpreted in its base position, where it is properly licensed. In Chapter 6, I present two experiments investigating the verbal NPI brauchen, which further corroborate the argument of this section.

\subsubsection{Sentential negation: C-commanding the verbal base-position}

Negation allows us to construct an even more general argument for obligatory reconstruction: As I will show, only obligatory reconstruction of the finite verb explains how sentential negation in V2-clauses with a single verbal element can be derived.

Negation may vary in its scope domain, as roughly indicated by the brackets in (62). Only the negation in (62a) can receive wide scope as sentential negation with the effect of reversing the truth value of the respective affirmative sentence. The

28 Many thanks to all researchers that contributed to the Collection of Distributionally Idiosyncratic Items (CoDII). The website hosts a rich data base of German polarity item which makes reasearch on these guys a lot easier. It is available at https://www.english-linguistics.de/codii/ index.html, where more information about contributors, research institutes, and funding are available. For references and several other German NPIs that are not yet included in the CODII data base see Richter et al. (2010). 
negation in (62b) takes only narrow scope (constituent negation) and excludes the respective constituent from the otherwise positive statement. ${ }^{29}$

a. [Letztlich hat Christopher seinen Bruder nicht besucht]. finally has Christopher his brother not visited 'Eventually, Christopher didn't visit his brother. (But he will go for breakfast with his aunt today.)'

b. Letztlich hat Christopher [nicht seinen Bruder] besucht. finally has Christopher not his brother visited 'Eventually, Christopher visited not his brother (but his girl friend).'

From a semantic perspective, it is somewhat surprising that sentence negation is not realized by an initial negation that takes surface scope over the entire clause structure, as noted by Zeijlstra (2007). In the German examples in (62) it even seems that the sentential negation occurs very low in the structure. How can this be explained? The expression of negation in natural languages shows considerable typological variation (Zanuttini 2001, Miestamo 2007) but one generalization seems to hold: sentential negation must c-command the highest verbal element of the clause. ${ }^{30}$ Haider (2012: 138-139) states that negation (and high adverbials) must c-command the element that situates the event variable in order to receive wide scope. This element is the finite verb in finite clauses and the highest non-finite verb in non-finite clauses. Accordingly, the negation in (62a) must have scope over the finite auxiliary hat or the whole verbal complex besucht hat respectively. Example (63) demonstrates that the base position of the negation is within the VP, in a preverbal position. Note that the order of arguments and negation reflects the base generated order because $w h$-indefinites do not scramble.

Da hat [vP wer wen nicht besucht hat].
there has someone.Nom somebody.Acc not visited
'Someone didn't visit somebody.' (see Haider 2012: 138)

The negation scope becomes even more evident in (64a). Here the sentence contains only one verbal element. This verb must be finite and therefore moves to the V2-position. Hence it left the c-command domain of the negation. The structure in (64a), however, is still interpreted as sentence negation. Under the assumption

29 Constituent negation may be ultimately subsumed as an association with focus phenomenon (see Section 3.3.1). I will not go into detail here.

30 In verb-initial languages, the negation therefore occurs in pre-VP positions, whereas in verbfinal languages negation either occurs as a preverbal particle (German) or as postverbal particle or an affix (Korean, Turkish) (Zanuttini 2001, Miestamo 2007). 
that the finite verb is reconstructed and interpreted in its base position, this fact is readily explained. In its base position, the verb besuchte in (64a) is within the scope of the negation. Note that this mechanism was crucial to explain the licensing of the NPI-verb brauchen in the previous section. In a simplified matter, we might say that the negation must precede the head of the phrase over which it scopes. ${ }^{31}$

(64) a. Letztlich besuchte Christopher seinen Bruder nicht besuchte.

finally visited Christopher his brother not

'Finally Christopher didn’t visited his brother.'

b.

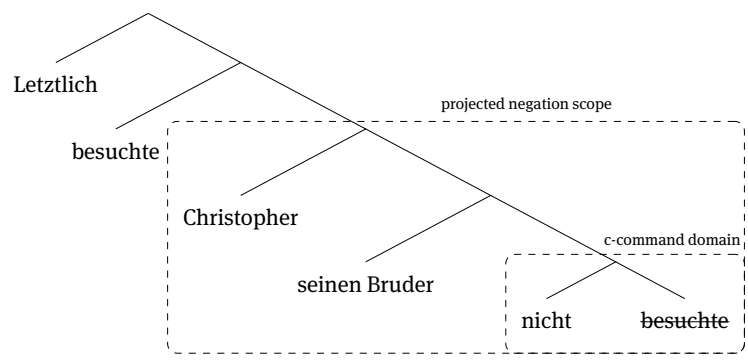

Note further that covertly raising sentential negation to a higher position in which it scopes over the V2-verb, as in (64a), is not a valid option. Such raising would predict that, under sentential negation, all NPIs that occur in a position lower than the V2-position should be licensed, contrary to the fact. (65a) shows that the NPI jemals 'ever' is ungrammatical in a position lower than the V2-position but higher than the sentential negation. In contrast, (65b) shows that jemals can be licensed in this very position by a licensor that scopes over the V2-position, here, the negative phrase auf keinen Fall 'in no way' in Spec-CP. ${ }^{32}$

31 Clearly this simplification ignores independent morphosyntactic restriction on the occurrence of negative markers (particles, affixes or auxiliaries, etc.). The shell structure of head-initial projection may induce additional problems. The reader is referred to Haider (2012) for a detailed discussion of these sort of configurational aspects.

32 Under such a raising account, the surface position of negative operators becomes irrelevant for the identification of their scope domain. Hence, we loose the ability to explain the differences in negation placement in OV- vs. VO-languages. This difference, however, appears to be very robust, even in the Scandinavian languages, which combine both properties, being V2languages and VO-languages. Hence, we must reject accounts that rest on LF-raising of the sentential negation. 
a. Letztlich besuchte Christopher $\left({ }^{\star}\right.$ jemals $_{\mathrm{NPI}}$ ) seinen Bruder nicht finally visited Christopher ever his brother not besuchte.

b. [Auf keinen Fall $]_{\mathrm{LIC}}$ besuchte Christopher jemals NPI $_{\text {seinen Bruder }}$ at no case visited Christopher ever his brother besuchte.

'In no way did Christopher ever visit his brother.'

Since the negation does not raise, the only explanation for sentential negation in sentences like (64a) is that the lexical verb reconstructs into its base position where it is within the scope of the negator, as illustrated in (66).

(66) Letztlich -te Christopher seinen Bruder nicht besuch-te. finally 3SG Christopher his brother not visit

'Finally, Christopher didn't visit his brother.'

The generalization about negation in German also correctly captures the observation that, in constituent negation, the negation directly precedes the negated constituent: This is illustrated for head-initial phrases, such as the PP (the locative adverbial) in (67a), and the DP (the object) in (67b), as well as for bare heads, such as the pronoun in (67c), and the adjective inside the object-DP in (67d). ${ }^{33} \mathrm{Ad}$ ditionally, the generalization correctly predicts that preverbal negation in German is superficially ambiguous between sentential negation in (67e) and verb negation in (67f), even though both cases may be distinguished by phonological means.

a. Gestern hat er den jungen Professor [nicht [in der Universität]] yesterday has he the young professor not in the university gefunden hat.

found

'Yesterday he did'nt find the young professor in the university.'

b. Gestern hat er [nicht [den jungen Professor]] in der Universität gefunden hat.

33 Peter Culicover (p. c.) and Josef Bayer (p. c.) noted that the situation is a little more complex, because there are examples in which the negator is embedded within PPs or complex DPs, as in (i), and still scopes out of these complexes to licence NPIs in the c-command domain of the head node of these complexes (see also Bruening 2014):

(i) a. [[Not many professors' $]_{L I C}$ students] expect anything ${ }_{N P I}$ when the professors retire.

b. I talked [to [no one $]_{L I C}$ ] about any ${ }_{N P I}$ of the problems.

Josef Bayer pointed out that the problem disappears if the feature of the negator is properly activated via agreement, as proposed in Bayer \& Bader (2007). 
c. Gestern hat [nicht er] den jungen Professor in der Universität gefunden hat.

d. Gestern hat er [den [nicht jungen] Professor] in der Universität gefunden hat.

e. Gestern hat er den jungen Professor in der Universität [nicht [gefunden hat]].

f. Gestern hat er den jungen Professor in der Universität [nicht gefunden] hat.

This projection of negation scope can be illustrated even more explicitly by clause union effects with German verb clusters (Haider 2010: 19, 272-292), an observation that dates back to Bech (1955). Consider the ambiguous sentence in (68), for example. The preverbal negation can either be interpreted as applying only to the adjacent infinitive, as in (68a), or as scoping over the whole verb cluster, thereby receiving wide scope, as in (68b). If the non-finite complement is extraposed, the scope of the negation is unambiguous: Preceding the infinitive, it only scopes over the embedded clause, as in (68c), whereas it has matrix scope when it precedes the matrix verb, as in (68d).

(68) Der Vater hat ihn nicht zu stören versucht.

the father has him not to disturb tried

a. Der Vater hat ihn [nicht zu stören] versucht. the father has him not to disturb tried 'The father tried not to disturb him.'

b. Der Vater hat ihn [nicht [zu stören versucht]]. the father has him not to disturb tried 'The father did not try to disturb him.'

c. Der Vater hat $t_{1}$ versucht, [ihn [nicht zu stören] $]_{1}$. the father has tried him not to disturb 'The father tried not to disturb him.'

d. Der Vater hat $t_{1}$ [nicht versucht], [ihn zu stören] $]_{1}$. the father has not tried him to disturb 'The father did not try to disturb him.'

Further support for the reconstruction of the finite verb comes from VP-topicalization patterns. Huang (1993: 132-135) noted that topicalized VPs in German reconstruct (see also Bayer 1993: 7-8, fn. 10), as evidenced by binding facts in (69). ${ }^{34}$ The

34 Pronouns in German tend to appear early in the middle field, i. e. preceding the adverbials and particles in (69). I will ignore this for the moment. 
reciprocal pronoun einander 'each other' in (69a) must be c-commanded by the antecedent die Raufbolde 'the roughecks' in order to be properly bound. The personal pronoun ihm 'him' in (69b), in contrast, must be c-commanded by the antecedent Christopher in order to exclude co-reference, as indicated. In both cases, the topicalized VP must reconstruct into its base position.

a. [Einander $r_{i / \star_{j}}$ verziehen] haben die Raufbolde $e_{i}$ dann doch noch each other forgive have the roughnecks then PRT PRT einander $r_{i / *}$ verziehen haben

'Eventually the roughnecks did forgive each other.'

b. $\left[\mathrm{Ihm}_{*_{\mathrm{i}} / \mathrm{j}}\right.$ verziehen] hat Christopher ${ }_{\mathrm{i}}$ dann doch noch $\mathrm{ihm}_{\mathrm{*}_{\mathrm{i} / \mathrm{j}}}$ verziehen him forgiven has Christopher then PRT PRT hat 'Eventually Christopher did forgive him.'

Verb topicalization, as in (70a), may only front the non-finite verb and leaves the sentential negation behind. This structure still has both readings, with either constituent negation of the lexical verb, comparable to (67f), or sentential negation, comparable to (67e). If the negation, however, is fronted with the non-finite verb, as in (70b), it can only have narrow scope over the verb, as constituent negation. Interestingly, (70c) shows that, if a larger VP is topicalized, the sentential negation remains in its base position. In this way, it is ensured that the negation ccommands the whole verb complex, in which both the finite and non-finite verb are reconstructed, and thereby enabling sentential negation. ${ }^{35}$ In sum, these patterns show that under sentential negation elements of the verbal complex may be moved out of the c-command domain of the negation because they are reconstructed into these base positions (Haider 2012: 138-139).

a. Besucht hat [VP der Junge den Vater nicht besucht hat]. visited has the boy the father not 'As for visiting, the boy didn't visit the father.' WIDE SCOPE/ 'The boy didn't VIsited the father.' NARROw SCOPE

35 Note that this is different for at least $w h$-indefinites. There, the indefinite must be reconstructed below the negation. The interpretation of (i) means that there was no one that the boy has visited, not that there was one specific person that he did not visit, see also Footnote 24 in Section 3.3.2.

(i) Wen besucht hat [ ${ }_{V P}$ der Junge (jedenfalls) nicht wen besucht hat]. someone visited has the boy PRT not 'Finally, the boy didn't visit anyone.' 
b. [Nicht besucht] hat [VP der Junge den Vater [nichtbesucht] hat], not visited has the boy the father sondern angerufen.

but called

'Not visited, that was what the boy did with the father, but called.'

c. [Den Vater besucht] hat [VP der Junge den Vater (jedenfalls) [nicht the father visited has the boy PRT not besucht hat]].

'The boy did not visit the father.'

Haider (2012) argues that a very similar argument can be made for high sentence adverbials, such as leider 'unfortunately'. He claims that adverbials must c-command their modification domain or at least the head of the respective projection. This leads to the same typological difference as with negation: In OVlanguages, like German, high sentence adverbials can appear VP internal but in VO-languages, such as English, sentence adverbial must precede the VP. A detailed discussion of the placement of adverbials would go beyond the scope of this section. I therefore refer the reader to Haider (2012: 139).

Summing up: The argument of this section is based on the assumption that semantic operators, such as negation, must c-command the head of their scope domain. For sentential negation this domain consist of the whole VP in VOlanguages but only the verbal complex in OV-languages. In V2-clauses (of OV- and VO-languages alike) the finite verb, however, is moved out of the scope domain of the sentential negation. The V2-Reconstruction Hypothesis offers an explanation why this does not affect scope relations: The finite verb is reconstructed into its base position for interpretation. In its base position, the finite verb is within the c-command domain of the sentential negation. Scope taking therefore applies in the same way as in verb-final subordinate clauses. The V2-Reconstruction Hypothesis therefore offers a principled account of the computation of the scope domain of sentential negation in V2-clauses.

\subsubsection{Summary: Lexical interpretation only in the base position}

In this section, I have presented three phenomena in favor of an obligatory reconstruction of the finite verb in V2-contexts. The two phenomena verbal NPIs and sentential negation showed that the finite verb has to be interpreted in the clausefinal position to license the NPI and to enable wide scope of the negation, respectively. The discussion of focus-sensitive operators associated with focused finite verbs went even further and suggested that the finite verb is interpreted only in 
its base position, which is indicated by the absence of an emphatic markedness which is observed in all other configurations of an inverted order of focus-sensitive operator and focus constituent.

\subsection{Experiment 1: The lexical meaning of periphrastic tun (acceptability judgments)}

\subsubsection{Rationale}

Introductory information about the tun-periphrasis in German is given in Section 3.2.2. There, I noted that a number of authors have stated that certain verbs are incompatible with periphrastic tun for semantic reasons, even though the characterization of the verb classes vary: agentive vs. non-agentive verbs (Fischer 2001: 40), eventive vs. stative verbs (Hoekstra 2016: 342), telic vs. atelic verbs (Schönenberger \& Penner 1995: 318-319), and individual-level vs. stage-level predicates (Bayer \& Freitag 2020). Clearly, all these characterizations build on the intuition that tun 'do' specifies an activity. However, as Bayer \& Freitag (2020: 83) note, also stative verbs seem quite acceptable with periphrastic tun, as long as they can be interpreted as stage-level predicates, i. e. denoting a temporary property/state, as in (71).

(71) Die Clarissa tut den ganzen Tag auf dem Sofa liegen. the Clarissa does the whole day on the sofa lie

'Clarissa is lying on the sofa the whole day.' (Bayer \& Freitag 2020: 83)

Rothmayr (2009) provides a detailed investigation of stative verbs, building on earlier work by Maienborn (2003, 2005, 2007). She distinguishes two different kinds of stative verbs: D(avidsonian) statives and K(imian) statives. ${ }^{36}$ The two classes differ with respect to the ontological type of argument they take. D-states, such as sleep, contain an event argument, whereas K-states, such as weigh, exemplify a property $\mathrm{P}$ at a particular time. Some typical representatives are given in $(72){ }^{37}$

a. Davidsonian statives:

sitzen 'sit', stehen 'stand', liegen 'lie', schlafen 'sleep', warten 'wait', leuchten 'gleam'

36 The terminology refers to work by Davidson (1967) and Kim (1976).

37 Clearly, some verbs can have more than one meaning, thereby occurring in more than one class, such as Clarissa lies on the couch as D-state (an event), and Constance lies on a lake as a K-state (a property), see Rothmayr (2009: 37-107) for more on these stative/eventive ambiguities. 


\section{b. Kimian statives:}

intelligent sein 'be intelligent', müde sein 'be tired', wiegen 'weigh', kennen 'know', wissen 'know', ähneln 'resemble'

(see Rothmayr 2009: 7)

Rothmayr (2009: 28-36) presents several diagnostics to distinguish D-states from K-states. Most relevant in the current context is the compatibility with periphrastic tun, which she judges perfectly fine with activity verbs as in (73a), clearly unacceptable with K-states as in (73b), and marginal with D-states as in (73c). ${ }^{38}$

(73) a. Josef tut gerade diese Doktorarbeit lesen.

Josef does right now this dissertation read

'Josef is reading this dissertation right now.'

b. * Josef tut diese Oper gut kennen.

Josef does this opera well know

c. ?/?? Josef tut verlegen in der Ecke stehen.

Josef does bashfully in the corner stand

(see Rothmayr 2009: 30-31)

A further diagnostic is that event nominalizations in German can be formed with the suffix -erei or the circumfix $G e-. . .-e$, which is possible with activity verbs as in (74a) and D-states as in (74c). With K-states, on the other hand, such nominalizations are out, as shown in (74b), because they do not contain an event argument.
a. lesen - Les-erei - Ge-les-e read reading reading
b. kennen - Kenn-erei $-{ }^{\star}$ Ge-kenn-e - z. B. *das Opern-Gekenne know knowing knowing e.g. the opera-knowing
c. stehen - Steherei - Ge-steh-e stand standing standing

Additionally, Rothmayr (2009) exemplifies three diagnostics that are based on adverbial modification with manner adverbials, locative modifiers, and degree readings of ein bisschen 'a little bit'. The rationale is the same for these three diagnostics: The modification targets an event. Hence, they are incompatible with K-states. I will only illustrate this for manner adverbials with the unavailability of manner modification for K-states in (75b), in contrast to activity verbs and D-states in (75a) and $(75 \mathrm{c})$, respectively.

38 Rothmayr (2009: 31) marked the example with a D-stative, corresponding to (73c), only with an asterisk, although she describes it as marginal in the text. Maienborn (2003: 63, ex. 41) marks these sentences with a ?. I therefore changed the judgement marking accordingly. 
(75) a. Josef liest diese Doktorarbeit aufmerksam/ gründlich. Josef reads this dissertation attentively thoroughly 'Josef reads this dissertation attentively/thoroughly.'

b. Josef kennt diese Oper *aufmerksam/ * gründlich. Josef knows this opera attentively thoroughly 'Josef knows this opera *attentively/thoroughly'39

c. Josef steht bewegungslos/ aufrecht in der Ecke. Josef stands motionless upright in the corner 'Josef stands motionless/upright in the corner' (see Rothmayr 2009: 30-31)

In contrast to the distinction of stage-level/individual-level predicates, the division of statives into D-states and K-states refers to the internal structure of the predicates and not to their discourse status. The crucial observation for this claim is that in copular constructions both stage-level and individual-level predicates express a K-state (see Rothmayr 2009: 3-28 for a comprehensive overview of the accounts of event semantics). As for the purpose of this section, this classification provides the basis for the following experiment, in which I will test the predictions regarding the varying compatibility of K-states and D-states with periphrastic tun, illustrated in (73). Additionally, I will test the prediction from Section 3.2.2 , i. e. that such incompatibilities are absent in VP-topicalizations, where tun is directly inserted in $\mathrm{C}$ to satisfy the V2-requirement. ${ }^{40}$

\subsubsection{Method}

\subsubsection{Participants}

In this experiment, 49 participants (19-37 years, mean 23 years; 8 male; 4 left handed) were tested, all self-declared native speakers of German ( 5 bilinguals) and students of the University of Cologne. Participants either received course credits or $4 €$ for participation.

39 Thoroughly seems to be unmarked in this context. I suspect that this is because it can have a meaning in which it describes the property of the state of knowledge in the sense of 'know st. very good'. It therefore does not count as a manner modification in the intended sense, in contrast to German gründlich or reading thoroughly. Thanks to Katie Fraser (p.c.) for sorting this out.

40 The observation that the aspectual incompatibility vanishes in VP-topicalization is also noted by Maienborn (2003: 62, fn. 12), however, without offering any explanation for it. 


\subsubsection{Materials}

Materials consisted of 36 experimental items interspersed with 44 fillers ( 28 from a different experiment) resulting in a total of 80 stimuli per participant. Every stimulus was introduced by a short context (1-3 sentences). The experimental items varied in two factors, Verb Type and Clause Type. The Verb Type was fixed for the lexical variants. CLAUSE TYPE varied within the lexical variants, as illustrated by the sample items in (76)-(78). For each VERB TYPE, at least three structural variants, as exemplified in Table 3.2, were tested to obtain a representative sample of the verb class. In the VP-TOPICALIZATION condition, for most items, the whole VP, including complements, is fronted whereas in others only the infinitival verb appeared in initial position. All items are given in the online appendix.

(76) ACTIVITY

a. Context:

Derzeit geht es ihr zu langsam voran. Also wirft die Chefin der Autowerkstatt einen Blick durch die Scheibe in den Werkstattraum.

'At the moment, she considers the progress to be too slow. So the boss of the garage takes a look through the window into the workroom.'

b. LEXICAL V2

Der Lehrling repariert immer noch den alten Golf. the apprentice repairs still the old Golf

'The apprentice is still repairing the old VW Golf.'

c. TUN-PERIPHRASIS

Der Lehrling tut immer noch den alten Golf reparieren. the apprentice does still the old Golf repair

'The apprentice is still repairing the old VW Golf.'

d. VP-TOPICALIZATION

Den alten Golf reparieren tut der Lehrling immer noch. the old golf repair does the apprentice still 'What the apprentice is still repairing is the old VW Golf.'

(77) K-sTATES

a. Context:

Taucher haben das Wrack eines uralten Schiffes gefunden. Es scheint beinahe senkrecht nach unten gesunken zu sein.

'Scuba divers have found the wreck of a very old ship. It seems to have sunk almost upright.' 
b. LEXICAL V2

Die Bugspitze steckt jedenfalls metertief in dem schlammigen the nose sticks in any case meters deep in the muddy Meeresboden.

sea ground

'The nose sticks in any case several meters deep in the muddy sea ground.'

c. TUN-PERIPHRASIS

Die Bugspitze tut jedenfalls metertief in dem schlammigen the nose does in any case meters deep in the muddy Meeresboden stecken. sea ground stick

'The nose sticks in any case several meters deep in the muddy sea ground.'

d. VP-TOPICALIZATION

Metertief in dem schlammigen Meeresboden stecken tut die meters deep in the muddy sea ground stick does the Bugspitze jedenfalls.

nose in any case

'What the nose does is stick meters deep in the muddy sea ground.'

(78) D-STATES

a. Context:

Eine Patientin wird mit hohem Fieber ins Krankenhaus eingeliefert. Allerdings sieht man ihr die Temperatur kaum an.

'A patient is brought to the hospital suffering from intensive fever. However, the high temperature is hardly noticeable when looking at her.'

b. LEXICAL V2

Die Patientin schwitzt lediglich an den Beinen.

the patient sweats solely at the legs

'The patient sweats only from her legs.'

c. TUN-PERIPHRASIS

Die Patientin tut lediglich an den Beinen schwitzen.

the patient does solely at the legs sweat

'The patient sweats only from her legs.' 


\section{d. VP-TOPICALIZATION}

Schwitzen tut die Patientin lediglich an den Beinen. sweat does the patient solely at the legs

'The patient sweats only from her legs.'

Table 3.2: Structural variant of the verb types used in experiment 1

\begin{tabular}{|c|c|c|}
\hline subtypes & $\mathbf{n}$ & example \\
\hline \multicolumn{3}{|r|}{ ACTIVITY } \\
\hline inanimate object & $(4 / 12)$ & das Auto reparieren 'repair the car' \\
\hline animate object & $(4 / 12)$ & den Sohn umarmen 'hug the son' \\
\hline PP-complement & $(4 / 12)$ & über die Bahn schimpfen 'grumble about the railroad' \\
\hline \multicolumn{3}{|r|}{ K-STATES } \\
\hline position & $(4 / 12)$ & im Boden stecken 'stick in the ground' \\
\hline ES possesor & $(4 / 12)$ & dem Vater ähneln 'resemble the father' \\
\hline measure & $(4 / 12)$ & $2 €$ kosten 'cost $2 €$ ' \\
\hline \multicolumn{3}{|r|}{ D-STATES } \\
\hline position & $(4 / 12)$ & im Weg stehen 'stand in the way' \\
\hline internal cause & $(4 / 12)$ & grün leuchten 'glow green' \\
\hline PP-complement & $(1 / 12)$ & aufden Anruf warten 'wait for the call' \\
\hline other & $(3 / 12)$ & an den Beinen schwitzen 'sweat on the legs' \\
\hline
\end{tabular}

\subsubsection{Procedure}

The experiment was conducted as a rating task with a reference sentence (anchor) and an open scale, similar to thermometer judgments (Featherston 2008, 2009). The current task design was as follows: Participants were provided with a single reference sentence (79), a declarative with a center-embedded object clause, which is possible but dispreferred to the variant with the embedded clause rightextraposed. This reference sentence was associated with a score of 0 . Participants were asked to judge the acceptability of the target sentences in comparison to the reference sentence. Instruction asked if sentences are better or worse, easier or harder to understand. It was stated explicitly that it is not asked for prescriptive rules or "good" writing style. The instructions also provided some examples with respective proposals for scores. 
(79) Die Angestellten haben, dass der Chef Probleme hat, nicht sofort the employees have that the boss problems has not immediately bemerkt. noticed

'The employees did not immediately notice that the boss has problems.'

If a target sentence was worse than the reference sentence, participants should associate a negative score. If it was better, they should assign a positive score. The number range was open but only integers allowed.

The procedure was programmed in the python experiment suite PsychoPy (Peirce 2007) and run on a PC in a psycholinguistic lab. Participants saw four practice items to get acquainted with the task. The experimental stimuli were randomized according to a partial Latin square design, ${ }^{41}$ so each participant saw each of the 36 items in exactly one of the three structural variants. The total list of stimuli was randomized by the experiment software. The experiment took approximately 20 minutes.

\subsubsection{Predictions}

According to the claims in the literature and the argumentation above, I expect an interaction of VERB TYPE and CLAUSE TYPE that looks as follows: No verb-specific effect should appear in the LEXICAL V2 condition because V2-movement is insensitive to the lexical meaning of the verb. In the TUN-PERIPHRASIS condition, I expect an effect of verb type with clearly higher acceptability ratings for ACTIVITY in comparison to the other two verbs. Additionally, D-STATES should be a little more acceptable than K-STATES. Furthermore, no verb-specific effect is predicted in the VPTOPICALIZATION condition because the tun is semantically empty. However, the ratings for VP-TOPICALIZATION should be higher than for the TUN-PERIPHRASIS because VP-TOPICALIZATION does not contain a semantic incompatibility. This prediction is restricted to the K-STATES and D-STATES verb, that are marked in the TUN-PERIPHRASIS construction. Obviously, the LEXICAL V2 condition is expected to receive higher ratings because it is an unmarked construction with respect to pragmatics and information structure, whereas the TUN-PERIPHRASIS and the VPTOPICALIZATION are marked in this respect.

\subsubsection{Data analysis}

Prior to statistical analysis, all emtpy cells have been removed ( $n=21,0.5 \%$ of the data). Additionally, I excluded 4 extreme values after data inspection. These val-

41 The Latin square was restricted because VERB TYPE was fixed per item, as noted above. 
ues are all singular outliers, which are more than 4 standard deviations away from the participants' mean and therefore most likely constitute typos. I analyzed the data using the statistical software package $\mathrm{R}$ (R Core Team 2015), applying linear mixed-effects models of the lme 4 package (Bates et al. 2013) to analyze the Ztransformed response scores. Following arguments in Barr et al. (2013) and Bates et al. (2015), I fitted maximal justified random effect structures for the LME-models. I performed a model criticism as recommended in Baayen \& Milin (2010) by excluding absolute standardized residuals exceeding 2.5 standard deviations. I report the results of the criticized model, taking effects as significant if the respective $t$-value exceeds an absolute value of 2 .

In response to the predictions above, I will employ separate analysis of subsets of the data. In a first analysis, I will compare the syntactic configurations (CLAUSE TYPE). The second analysis will investigate the effect of VERB TYPE within each of the three configurations. The third analysis will test for each verb type, whether the syntactic configuration correlates with the acceptability.

\subsubsection{Results}

A graphical summary of the results is presented in Figure 3.1 The primary analysis revealed a main effect of CLAUSE TYPE with much higher values for LEXICAL V2 structures than for TUN-PERIPHRASIS and VP-TOPICALIZATION $(t=29.91)$, see Table 3.3. No difference between the two latter condition could be detected. The secondary analyses detected VERB TYPE-specific effects only within the TUN-PERIPHRASIS condition, but no differences in the LEXICAL V2 or the VPTOPICALIZATION group. Within the TUN-PERIPHRASIS group, the ACTIVITY verbs received significantly higher ratings in comparison to the K-sTATES verbs $(t=$ -2.126). Mean rating for the D-STATES ranges between the two other conditions and is not significantly different from either of them, at least after model criticism $(t=-1.237)$, which indicates that the significance in the raw model is driven by outliers, see Table 3.4. The tertiary analysis of the D-STATES and the K-STATES condition confirmed the above results. Within both groups, only the extreme difference of the LEXICAL V2 condition in comparison to the other two constructions yields significance. All other contrasts remain non-significant.

\subsubsection{Discussion}

The results match most of the predictions. Foremost, the expected interaction of ClAuSE TyPe and Verb TyPE could be detected. TUN-PERIPHRASIS received 

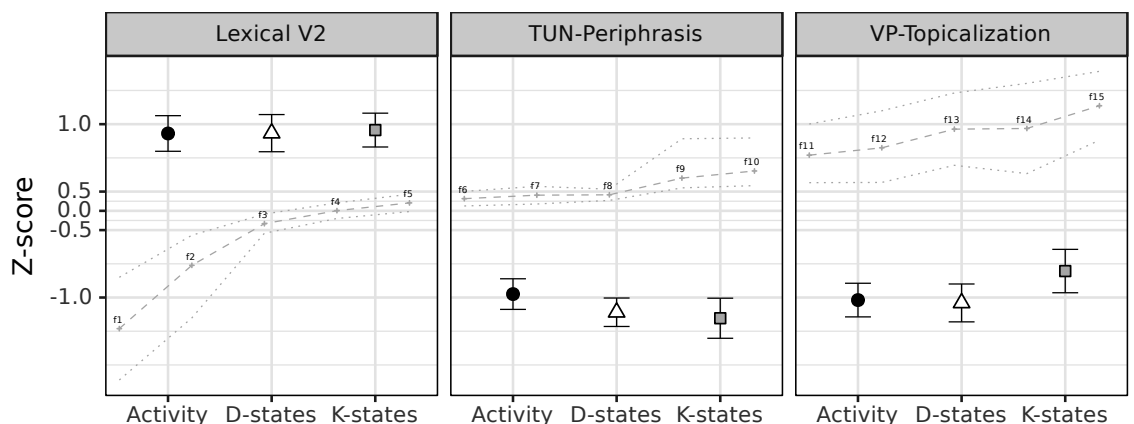

Figure 3.1: Mean Z-scores of the acceptability ratings of experiment 1 . The background shows the acceptability of the independent fillers (all errorbars show $95 \% \mathrm{Cls}$ ). Note the compressed scale in the middle of the $Y$-axis.

Table 3.3: Output of the LME model for the CLAUSE TYPE-analysis in experiment 1 lmer (Z. score $\sim$ clause. type+(1+clause. type | participant. ID)+ $(1+$ clause. type|stimulus. ID))

\begin{tabular}{lrrrrrr}
\hline & \multicolumn{3}{c}{ criticized model } & \multicolumn{3}{c}{ raw model } \\
\cline { 2 - 8 } & Estimate & SE & \multicolumn{1}{c}{$\mathrm{t}$} & Estimate & SE & \multicolumn{1}{c}{$\mathrm{t}$} \\
\hline Intercept (TUN-PERIPHRASIS) & -1.06 & 0.05 & -22.07 & -1.05 & 0.05 & -19.07 \\
LEXICAL V2 & 2.04 & 0.07 & 29.91 & 2.01 & 0.07 & 26.92 \\
VP-TOPICALIZATION & 0.07 & 0.07 & 0.98 & 0.07 & 0.07 & 0.98 \\
\hline
\end{tabular}

Table 3.4: Output of the LME model for the TUN-PERIPHRASIS-analysis in experiment 1 $\operatorname{lmer}$ (Z.score verb. type+trial+(1+verb. type+trial|participant. ID)+(1|stimulus. ID))

\begin{tabular}{lrcrrrr}
\hline & \multicolumn{3}{c}{ criticized model } & \multicolumn{3}{c}{ raw model } \\
\cline { 2 - 7 } & Estimate & $\mathrm{SE}$ & $\mathrm{t}$ & Estimate & $\mathrm{SE}$ & $\mathrm{t}$ \\
\hline Intercept (ACTIVITY) & -1.024 & 0.049 & -20.727 & -0.971 & 0.059 & -16.500 \\
D-STATES & -0.038 & 0.031 & -1.237 & -0.100 & 0.043 & -2.322 \\
K-STATES & -0.086 & 0.040 & -2.126 & -0.114 & 0.052 & -2.191 \\
trial & -0.001 & 0.001 & -1.224 & -0.001 & 0.001 & -0.842 \\
\hline
\end{tabular}


higher ratings if combined with ACTIVITY verbs in clause-final position. This indicates that tun still retains its agentive meaning in these constructions. Hence, K-STATES receive the lowest rating because they do not exhibit a Davidsonian event argument. As predicted by Rothmayr (2009: 30-31), D-statives are marginal, i. e. they receive intermediate ratings. This differences between ACTIVITY and K-STATES is absent in the construction without tun, LEXICAL V2, and in the VPTOPICALIZATION, in which tun is semantically empty. These two comparisons show that the difference cannot be attributed to the verbs per se but is also construction specific. Furthermore, the LEXICAL V2 condition was rated much higher than the other conditions. The only prediction that could not be confirmed, is that the VP-TOPICALIZATION should receive higher ratings than the TUN-PERIPHRASIS group, at least for the stative verbs. However, VP-topicalizations are information structurally very marked. Their acceptability is therefore highly dependent on the licensing by the discourse. The context sentences of the current experiment were constructed with the goal to allow VP-topicalization without, or at least with a small penalty. The results indicate that this goal has not been accomplished.

In sum, experiment 1 was successful, in confirming that tun interacts with the meaning of the lexical verb in tun-periphrasis but not in VP-topicalizations. It provides a reliable data basis for the discussion of periphrastic tun, which often leads to diverging intuitions due to dialectal and register variation interacting with the sometimes subtle differences (see e. g. Erb 2001: 191-197).42

This experiment is only a first step in investigating the fine nuances of periphrastic tun. However, it provides a starting point for follow-up studies investigating more verb types, such as eventive verbs (erkennen 'realize'), configurational verbs (umgeben 'surround'), and experiencer verbs (interessieren 'interest'), as well as other syntactic constructions, such as VP-pronominalizations and pseudoclefts. Additionally, the overall acceptability of VP-topicalizations should be addressed by providing more supportive contexts in future experiments.

\subsection{Chapter summary}

In this chapter, I introduced the V2-Reconstruction Hypothesis which says that a V2-moved verb appears in an early position in the clause only to deliver finiteness features, but is always interpreted in its clause-final base position, which is known as reconstruction. I also exemplified that reconstruction is a quite frequent phenomenon in syntax that appears whenever a syntactic element is pied-piped

42 I thank Hans-Martin Gärtner for bringing Erb (2001) to my attention. 
by another element, i. e. it does not move because of its own features. The subsequent sections presented empirical evidence for the validity of the two subclaims of the V2-Reconstruction Hypothesis.

Section 3.2 showed that German exhibits systematic cases in which the lexical content of the finite verb is not interpreted in the V2-position, such as the stem of idiomatic particle verbs, tun-insertion in VP-topicalizations, and verb doubling. Additionally, Frisian wer-insertion and complementizer agreement illustrated that, if a complementizer is present in $\mathrm{C}$, the inflectional affixes attach to these complementizers without moving a verb into $\mathrm{C}$, and in fact, even blocking verb movement. This proves that not the verb has to move to $C$ but only the finiteness features, thereby supporting the first subclaim of the V2-Reconstruction Hypothesis.

In Section 3.3, I presented three phenomena which reveal that the V2-moved verb must be interpreted in its clause-final base position. Association with focus was used to show that only V2-movement can apparently invert the order between the focus-sensitive operator and the focus constituent without introducing markedness. The problem is solved under the assumption that the finite verb is only interpreted in it clause-final base position. Licensing of verbal NPIs construct a similar argument. V2-moved NPIs are apparently the only NPIs that may escape the c-command domain of their licensor. Again this behavior is readily explained under reconstruction analysis. Third, I have shown that the V2-Reconstruction Hypothesis explains why finite verbs precede sentential negation without escaping its scope. These phenomena show that the finite verb of V2-clauses is interpreted only in its clause-final base position, backing the second subclaim of the V2-Reconstruction Hypothesis.

In Section 3.4, I presented experimental evidence which supports the claims about the different semantic contribution of tun 'do', in periphrastic tun and VPtopicalization. The results show that tun leads to a semantic incompatibility with verbs that denote Kimian states, indicating that tun still retains some meaning. Such an incompatibility was not detectable for VP-topicalization indicating that, here, a semantically empty tun is inserted as a last resort operation to provide a host for the finiteness affixes in $\mathrm{C}$.

In sum, this chapter introduced the main topic of this investigation, the V2Reconstruction Hypothesis, and provided a range of empirical phenomena for its validity. Note that the assumption of a generalized reconstruction of the finite verb also allows a systematic simplification of the linguistic description of German clauses because explanations for all V-final counterparts of V2-clauses are needed anyway to analyze embedded clauses. In Part II of this monograph, I will illustrate that the predictions of the V2-Reconstruction Hypothesis concerning online sentence comprehension are borne out, too. 